\title{
VIAS DE SINALIZAÇÃO DESENCADEADAS PELA ESTIMULAÇÃO DO ADRENOCEPTOR $\beta$ EM CÉLULAS SECRETORAS DA GLÂNDULA DE VENENO DA SERPENTE Bothrops jararaca
}

\author{
Dissertação de Mestrado apresentada ao \\ Instituto de Ciências Biomédicas da \\ Universidade de São Paulo, para a obtenção do \\ Título de Mestre em Ciências.
}

Área de concentração: Biologia Celular e Tecidual

Orientadora:

Dra. Norma Yamanouye 
Aos meus pais, que sempre me amaram incondicionalmente.

Ao meu pai,

que sempre me incentivou

e me fez crescer.

À minha mãe, que me deu apoio e colo todas as vezes que precisei.

À minha querida irmã, que às vezes me deixa louca, mas que é muito especial. 
Ao Eduardo, meu namorado desde sempre, que está ao meu lado em todos os momentos da minha vida.

À família do Eduardo, que me acolheu como filha e da qual me sinto parte.

À minha orientadora, Dra.Norma Yamanouye, pessoa que me ensinou como fazer ciência e que me fez crescer como profissional e como pessoa. 


\section{AGRADECIMENTOS}

Ao Laboratório de Herpetologia do Instituto Butantan, pela classificação e fornecimento das serpentes Bothrops jararaca.

À Fapesp e ao CNPq, pelo auxílio financeiro.

À Fundação Butantan, pelo auxílio financeiro.

À Dra. Soraya S. Smaili, do Departamento de Farmacologia (UNIFESP) pela colaboração nos experimentos de fluorimetria, empréstimo de materiais e do fluorimetro, além de importantes sugestões para a realização deste trabalho.

À Dra. Regina P. Markus, do Departamento de Fisiologia do Instituto de Biociências (USP), pelo uso do Cytosensor e pelas importantes discussões acerca dos resultados obtidos.

À Dra. Zulma S. Ferreira, do Departamento de Fisiologia do Instituto de Biociências (USP), por me ensinar como fazer os experimentos de microfisiometria e por sempre estar disposta a me ajudar, além do bom humor costumeiro.

À Dra. Sylvia M. Carneiro, do Laboratório de Biologia Celular do Instituto Butantan, pela colaboração neste trabalho e pela realização da parte de Microscopia Eletrônica deste trabalho.

À Dra. Maria Cristina Breno, pela ajuda na anestesia de animais e pela agradável companhia no dia a dia do laboratório.

À Dra. Guiomar, à Dra. Hanako e à Tatiane do Departamento de Farmacologia (UNIFESP), pelo auxílio nos experimentos de fluorimetria.

À Dra. Celine Kerchove, por me ensinar quase tudo no laboratório, pela enorme ajuda durante a minha Iniciação Científica e parte do mestrado, além da amizade, companheirismo e muitos momentos alegres no laboratório.

À Milene, companheira de mestrado, pela agradável companhia, amizade e momentos muito divertidos. Obrigada também por me escutar e dar conselhos nos momentos mais difíceis. 
À Fernanda, pelo enorme auxílio na parte de microscopia eletrônica e pelas agradáveis conversas durante os experimentos.

Ao Thiago, pela agradável companhia e pela ajuda no uso de computadores.

À Aline, amiga que durante o tempo em que esteve no laboratório me alegrou "até demais" em todos os momentos e que até hoje me alegra.

À Celiana, por me ajudar todas as vezes que precisei.

À Camila e à Milene, pelos almoços animadíssimos que ficaram para a história.

Aos amigos "mais chegados" do Laboratório: Camila, Rafaela, Leonardo, Carina, Leandro, Marina, Wilson, Gustavo, Sayuri, Elisângela.

À todos os outros amigos e companheiros da rotina do Laboratório.

Às minha amadas amigas da Bio: Carol e Marcella pelas saídas divertidíssimas para a reunião da "Tríade", pela companhia em todos os momentos e pela amizade eterna.

À todos os meus amigos, que mesmo não participando diretamente deste trabalho, fizeram a minha vida mais feliz.

À toda a minha família, pelo suporte, incentivo e amor. 


\section{RESUMO}

A glândula de veneno de serpentes Viperidae possui um lumen central, onde todo veneno produzido é estocado. A diminuição do conteúdo de veneno do lumen, por exemplo, por extração manual de veneno, leva a glândula a produzir mais veneno. O ciclo de produção de veneno dura de 30 a 50 dias.

A inervação noradrenérgica possui papel importante para o ciclo de produção e secreção de veneno em glândula de veneno da serpente Bothrops jararaca. Os adrenoceptores $\alpha$ e $\beta$ presentes nesta glândula participam desses processos. $O$ adrenoceptor $\beta$ possui propriedades farmacológicas diferentes dos descritos em mamíferos e está presente na glândula de veneno tanto no estado quiescente como no ativado por 4 dias. Quando estimulado, aumenta os níveis de AMPc, mas somente em células secretoras no estado quiescente. $O$ objetivo deste trabalho é caracterizar funcionalmente o adrenoceptor $\beta$ durante o ciclo de produção de veneno e verificar seu papel na produção de veneno.

Neste trabalho, mostramos que a estimulação do adrenoceptor $\beta$ com isoprenalina promoveu aumento na taxa de acidificação do meio extracelular em células quiescentes $\left(\mathrm{pD}_{2}=3,92 \pm 0,17, \mathrm{n}=6\right)$ e ativadas por 4 dias $\left(\mathrm{pD}_{2}=3,68 \pm 0,27, \mathrm{n}=4\right)$, indicando que em células secretoras ativadas por 4 dias, o adrenoceptor $\beta$ está acoplado a outra via de sinalização, além da via clássica AMPc/PKA. Entretanto, em células ativadas por 15 dias, este receptor está dessensibilizado.

Mostramos também que isoprenalina promoveu aumento na concentração citosólica de cálcio em células quiescentes, tanto em meio com 2,5 mM de cálcio $(57,38 \pm 8,69 \%, n=7)$, 
como em meio nominalmente sem cálcio $(20,88 \pm 7,54 \%, n=7)$. Esse aumento ocorreu via canais de cálcio operados por voltagem e canais de cálcio operados por receptor e de liberação de cálcio de estoques intracelulares sensíveis a tapsigargina, respectivamente.

Já em células secretoras ativadas por 4 dias, o aumento de cálcio citosólico promovido por isoprenalina em células em meio com cálcio $(18,16 \pm 0,83 \%, n=3)$ ou em meio nominalmente sem cálcio $(7,50 \pm 1,60 \%, n=3)$ é significativamente menor do que em células quiescentes, mostrando que o adrenoceptor $\beta$ está dessensibilizado após sua estimulação, no início do ciclo de produção de veneno. PKA não participa desta sinalização, mas possui um papel importante na regulação de canais de cálcio no estado basal dessas células.

A dessensibilização dos adrenoceptores $\beta$ foi confirmada in vivo, onde serpentes reserpinizadas, as quais não produzem veneno, tiveram a síntese e secreção de veneno restauradas após uma única administração de isoprenalina logo após a extração de veneno.

Em conclusão, a estimulação do adrenoceptor $\beta$ presente na glândula de veneno da serpente Bothrops jararaca ativa várias vias de sinalização levando a um aumento na concentração de AMPc, de cálcio citosólico e da taxa de acidificação do meio extracelular. Este receptor tem como função desencadear o ciclo de produção de veneno. 


\section{ABSTRACT}

The venom gland of Viperidae snakes has a central lumen where the produced venom is stored. Biting and manual extraction of venom reduces the amount of venom inside the lumen, and stimulates the secretory cells to produce venom. The venom production cycle is long and lasts around 30 to 50 days. Noradrenergic innervation is important for the venom production cycle in Bothrops jararaca venom gland, and the stimulation of both $\alpha$-and $\beta$-adrenoceptors in the secretory cells of the venom gland is involved in venom production. $\beta$-adrenoceptors are present in quiescent and activated (4 days after venom extraction) stages of secretory cells but have low affinity to selective $\beta$-adrenoceptor ligands. They are coupled to Gs protein and undergo to desensitization just after stimulation, since only in quiescent cells and not in activated cells stimulation of $\beta$-adrenoceptors promotes an increase of cAMP concentration. In this work, we further functionally characterized the $\beta$-adrenoceptor in snake venom gland during venom production cycle, and its role in venom production.

Isoprenaline increased the rate of extracellular acidification in a dose-dependent manner in quiescent $\left(\mathrm{pD}_{2}=3.93 \pm 0.17, \mathrm{n}=6\right)$ and 4 days activated $\left(\mathrm{pD}_{2}=3.68 \pm 0.28, \mathrm{n}=4\right)$ cells with similar sensitivity, suggesting that the $\beta$ adrenoceptor is coupled to other signaling pathway, besides the classical cAMP/PKA. In 15 days activated cells, $\beta$ adrenoceptor is desensitized.

Isoprenaline increases citosolic calcium concentration in a dose-dependent manner by activating voltage-operated and receptor-operated calcium channels. However, the increase at the maximum dose used was significantly higher in quiescent 
cells $(57.38 \pm 8.69 \%, n=7)$ than in 4 days activated cells $(18.16 \pm 0.83 \%, n=3)$. Isoprenaline also mobilizes calcium from tapsigargin sensitive stores and the increase at the maximum dose used was significantly higher in quiescent cells $(20,88 \pm 7,54 \%$, $\mathrm{n}=7)$ than in 4 days activated cells $(7,50 \pm 1,60 \%, n=3)$. These data show that after venom extraction $\beta$-adrenoceptors undergo to desensitization. PKA does not participate in this signaling, but has an important role in regulating calcium channels in the basal state of quiescent secretory cells.

Depletion of endogenous catecholamines with reserpine block venom production and secretion and a single injection of isoprenaline (100 mg/kg, s.c.) immediately after venom extraction is able to restore the venom production and secretion.

Our data suggest that stimulation of $\beta$-adrenoceptor can signaling through different pathways and is relevant for the onset of the venom production cycle in snake venom gland. 


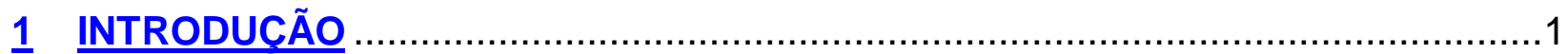

1.1 A glândula de veneno da serpente Bothrops jararaca...............................11

1.2 A inervacão noradrenérgica na glândula de veneno...................................15

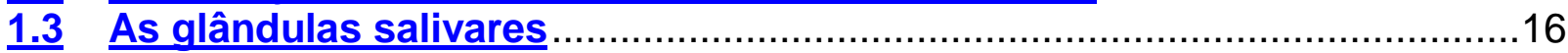

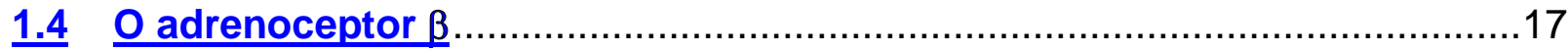

1.4.1 O adrenoceptor $\beta$ da glândula de veneno de Bothrops jararaca ..................19

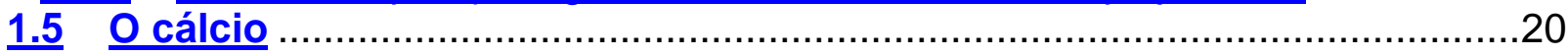

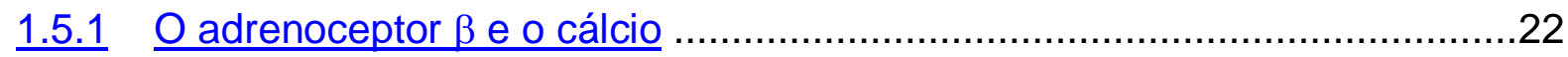

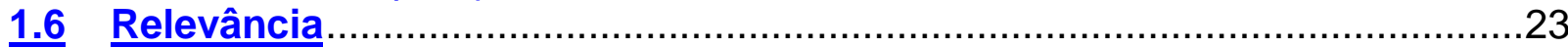

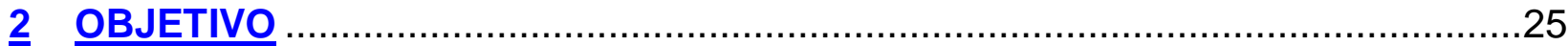

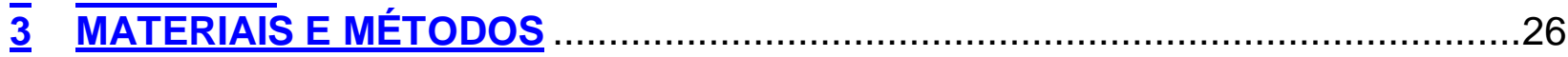

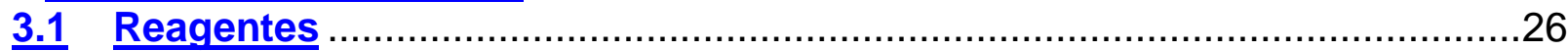

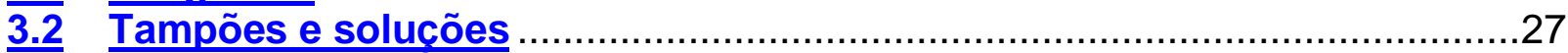

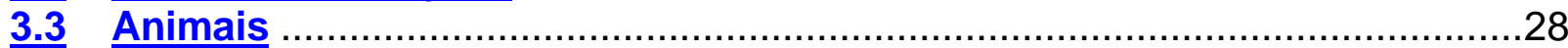

3.4 Funcionalidade do adrenoceptor $\beta$ durante o ciclo de producão de veneno 28

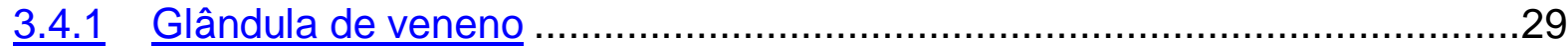

3.4.2 Dispersão de células secretoras de glândula de veneno ...........................29

3.4.3 Medida da taxa de acidificação extracelular por microfisometria em células

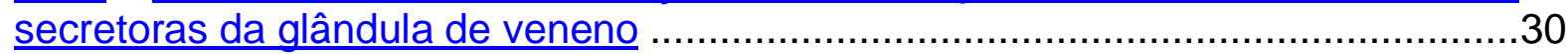

3.4.4 Medida de cálcio citosólico em células secretoras por fluorimetria ...............31

3.5 Estudo in vivo da participação do adrenoceptor $\beta$ na producão de veneno 33

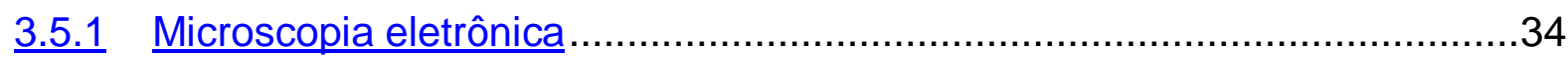

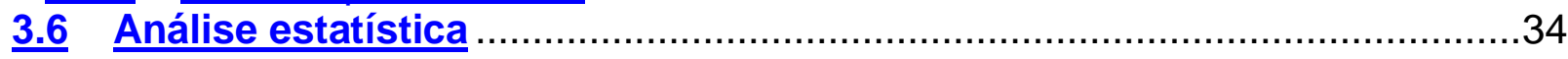

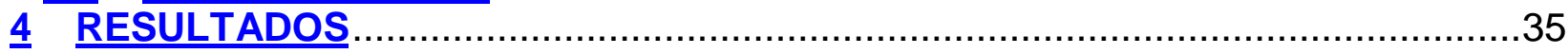

4.1 A estimulação do adrenoceptor $\beta$ promove aumento da taxa de

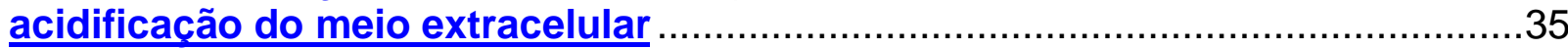
4.2 Isoprenalina induz aumento lento da concentracão de cálcio citosólico em

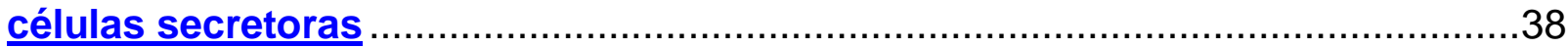

4.3 Canais de cálcio operados por voltagem e operados por receptor participam da sinalizacão promovida por isoprenalina

$\underline{4.4}$ Canais de cálcio sensíveis a tapsigargina participam da sinalização

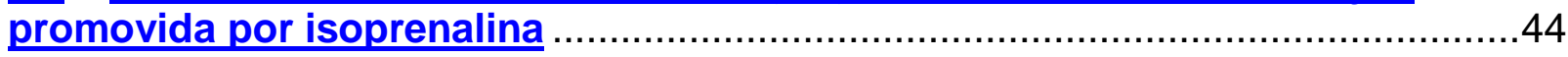

$\underline{4.5}$ Propranolol desencadeia aumento de cálcio intracelular …......................46

4.6 PKA participa da requlacão de canais de cálcio no estado basal das

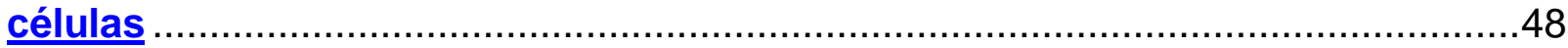

$4.7 \quad 0$ adrenoceptor $\beta$ desencadeia o ciclo de producão de veneno …...............50

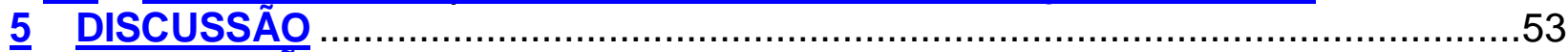

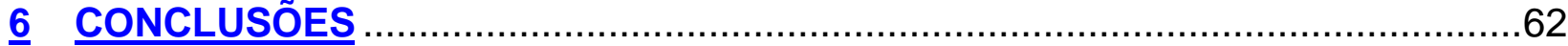

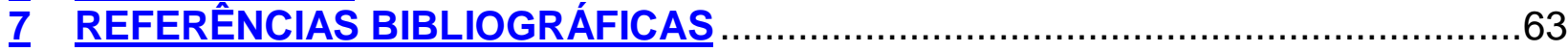




\section{INTRODUÇÃO}

\subsection{A glândula de veneno da serpente Bothrops jararaca}

As serpentes são animais que evoluíram a partir de ancestrais não venenosos e que pertencem à ordem Squamata, assim como os lagartos. Hoje em dia, há cerca de 2.900 espécies de serpentes no mundo, distribuídas em 465 gêneros e 20 famílias. No Brasil, temos representantes de 9 famílias, 75 gêneros e 321 espécies, equivalente a aproximadamente $10 \%$ do total das espécies (CARDOSO et al., 2003).

A serpente Bothrops jararaca (Wied, 1824) é peçonhenta e pertence à família Viperidae, subfamília Crotalinae (figura 1) e é encontrada do sul da Bahia até o Rio Grande do Sul. As serpentes do gênero Bothrops são responsáveis por 90,5\% dos acidentes ofídicos envolvendo seres humanos em todo o país (FUNASA, 2001) e, assim como todos os membros família Viperidae, a espécie Bothrops jararaca possui dentição do tipo solenóglifa, caracterizada por presas inoculadoras móveis situadas na porção anterior do maxilar e que é altamente eficaz na inoculação de veneno (GOMES; PUORTO, 1993). 


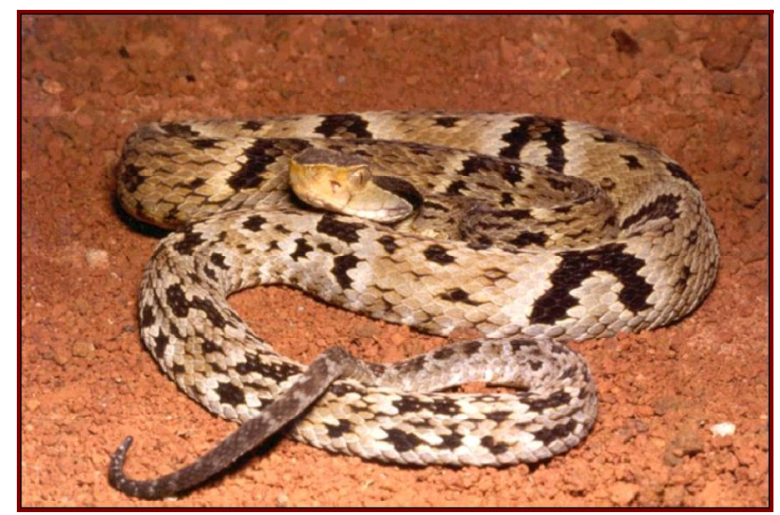

Figura 1: Serpente Bothrops jararaca (fotografada por Giuseppe Puorto).

As glândulas de veneno de serpentes da família Viperidae são relacionadas com as glândulas salivares e provavelmente evoluíram de glândulas salivares de ancestrais não venenosos (KARDONG, 1982; KOCHVA; GANS, 1970). O aparelho glandular de veneno se encontra na região temporal da cabeça e é formado por (figura 2): glândula principal de veneno, ducto primário, glândula acessória e ducto secundário, que se conecta à presa inoculadora de veneno (KOCHVA, 1978; KOCHVA; GANS, 1967; MACKESSY, 1991).

Nas serpentes da família Viperidae, a glândula de veneno possui um lumen central (figura 2) onde todo o veneno produzido é estocado (KOCHVA, 1978; KOCHVA; GANS, 1967; MACKESSY, 1991), diferindo de glândulas de veneno de serpentes das famílias Elapidae e Colubridae (GOPALAKRISHNAKONE; KOCHVA, 1993, 1990; KOCHVA, 1978; KOCHVA et al., 1980; YOSHIE et al., 1982) ou ainda de glândulas exócrinas de mamíferos (AMSTERDAM et al., 1969; JAMIESON; PALADE, 1967 a, b; MELDOLESI, 1976), nas quais o produto é estocado intracelularmente em vesículas secretoras. 
Há 4 diferentes tipos celulares na glândula de principal veneno de Viperidae: células secretoras, que representam cerca de $80 \%$ do total de células, células horizontais (cerca de 10\% do total de células), células "escuras" (aproximadamente 9\%) e células ricas em mitocôndrias (cerca de 1-2\%) (BEN-SHAUL et al., 1971; KOCHVA, 1978; KOCHVA; GANS, 1967; MACKESSY, 1991; WARSHAWSKY et al., 1973).

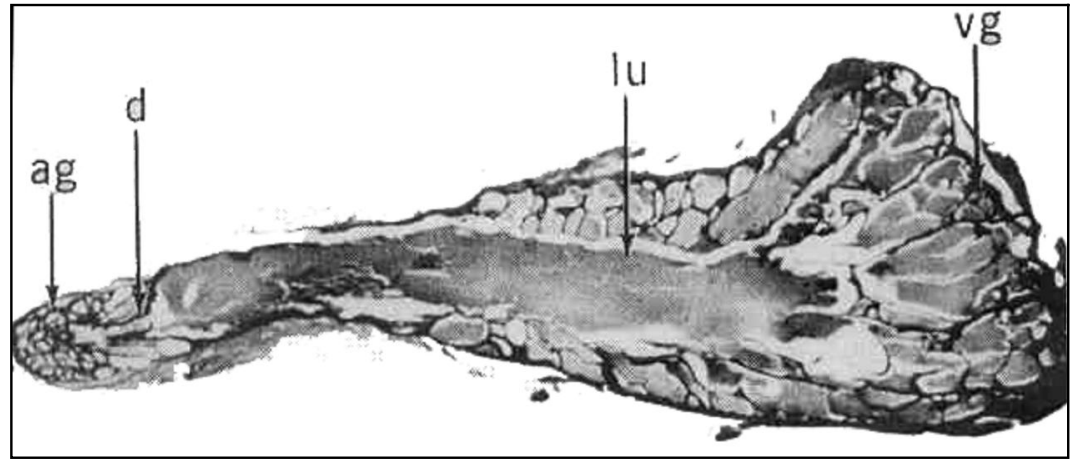

Figura 2: Corte longitudinal da glândula de veneno, sendo possível verificar a glândula principal de veneno (vg), o lumen (lu), o ducto primário (d) e a glândula acessória (ag) (KOCHVA, 1978).

Nas espécies da família Viperidae, a produção de veneno está vinculada à diminuição do conteúdo de veneno do lumen e após a extração manual de veneno ou uma picada, desencadeia-se o ciclo de produção e secreção de veneno (figura 3). Estudos feitos com as espécies Bothrops jararacussu (CARNEIRO et al., 1991), Crotalus durrisus terrificus (DE LUCCA et al., 1974), Vipera palestinae (BEN-SHAUL et al., 1971; ROTENBERG et al., 1971) e Crotalus viridis oreganus (MACKESSY, 1991), mostraram que o início deste ciclo é marcado por mudanças morfológicas e bioquímicas das células secretoras. As células inicialmente quiescentes (não ativadas) 
passam do formato cubóide para colunar, concomitantemente com a expansão das cisternas do retículo endoplasmático granular e ativação do Golgi. A maior concentração de RNA mensageiro é observada no $4^{\circ}$ dia após a extração de veneno. Já a maior atividade sintética ocorre entre $04^{\circ}$ e $08^{\circ}$ dia após a extração do veneno, sendo que atinge um platô por volta do $15^{\circ}$ dia. Após este período, as células retornam gradualmente à organização do estado quiescente (BDOLAH, 1979; BEN-SHAUL et al., 1971; CARNEIRO et al., 1991; DE LUCCA et al., 1974; KOCHVA, 1978; MACKESSY, 1991; ORON; BDOLAH, 1973; ROTENBERG et al., 1971; SALOMÃO, 1991; ZAGO, 1971). Este ciclo tem duração de 30 a 50 dias, um período longo quando comparado ao ciclo de produção de proteínas de glândulas salivares e pâncreas de mamíferos (AMSTERDAM et al., 1969; JAMIESON; PALADE, 1967a, b).

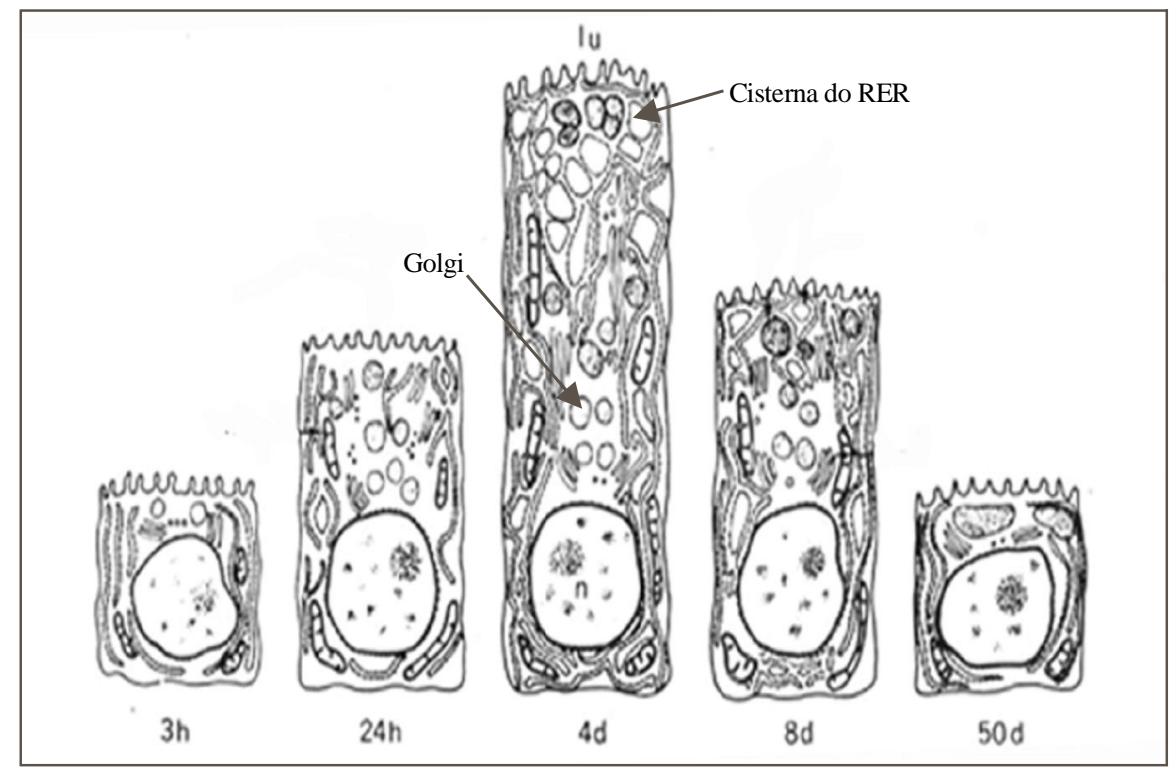

Figura 3: Esquema ilustrando as mudanças morfológicas ocorridas nas células secretoras da glândula de veneno de serpentes da família Viperidae durante o ciclo de produção de veneno (KOCHVA, 1987). 


\subsection{A inervação noradrenérgica na glândula de veneno}

Inicialmente sugeriu-se que os mecanismos que regulam a síntese e secreção da glândula de veneno não estivessem sob controle do sistema nervoso, uma vez que o seccionamento do nervo principal que supre a glândula não afetava quer a produção de veneno, quer a concentração protéica ou sua atividade enzimática (ALLON apud KOCHVA, 1978). Entretanto, estudos ultra-estruturais em glândula de veneno de serpentes Elapidae (Maticora bivirgata e Lapemis curtus) (GOPALAKRISHNAKONE; KOCHVA, 1990; 1993) mostraram a presença de terminais nervosos perto da base das células secretoras. Também foi verificado que o tratamento com isoproterenol, agonista do adrenoceptor $\beta$, é capaz de modificar a composição protéica tanto do veneno, como da própria glândula de veneno de serpentes Bothrops jararaca, sugerindo a importância da inervação simpática (NUÑES-BURGOS et al., 1993).

Somando-se a isso, Yamanouye et al. (1997) detectaram a inervação noradrenérgica nas glândulas de veneno da serpente Bothrops jararaca e demonstraram a sua relevância para a síntese e secreção de veneno, uma vez que o bloqueio da atividade simpática através do tratamento dos animais com reserpina, droga que depleta os estoques de noradrenalina, impede os processo de produção e secreção de veneno em glândulas estimuladas pela extração de veneno. Estas células apresentam retículo endoplasmático granular com cisternas paralelas e Golgi quiescente, indicativo da ausência de produção e secreção de veneno, respectivamente. No entanto, se o tratamento de reserpina é acompanhado por um tratamento crônico com fenilefrina (agonista do adrenoceptor $\alpha$, por 11 dias), ocorre a 
reversão do bloqueio promovido pela reserpina, promovendo a expansão das cisternas do retículo endoplasmático e ativação do Golgi, ou seja, são restaurados os processos de síntese e secreção de veneno. Já o tratamento crônico com isoprenalina (agonista do adrenoceptor $\beta$, por 11 dias) reverte parcialmente o bloqueio produzido pela reserpina, promovendo expansão das cisternas do retículo endoplasmático, ou seja, restaurando a síntese de veneno e demonstrando a importância do adrenoceptor $\beta$ para a produção de veneno em serpentes Bothrops jararaca (YAMANOUYE et al., 1997).

\subsection{As glândulas salivares}

A saliva é produzida nos ácinos salivares e é, inicialmente, um fluido isotônico. No ducto salivar, este fluido é modificado pela reabsorção de cloreto de sódio e secreção de potássio, tornando-se um fluido hipotônico (MARTINEZ et al., 1994). O processo de secreção do fluido salivar é mediado pelo sistema parassimpático, através de receptores muscarínicos. No entanto, a produção (ANN; LIN, 1998) e a secreção de proteínas salivares, como amilase e mucina, é controlada pelo sistema noradrenérgico, mais especificamente pela estimulação de adrenoceptores $\beta$ (LI et al., 2006; QUISSELL \& BARZEN, 1980; YAMADA et al., 2006). A estimulação de adrenoceptores $\beta$ em glândulas parótidas e submandibulares promove o aumento de adenosina monofosfato cíclico (AMPc) e este, por sua vez, leva à ativação de proteína quinase $A(P K A)$, que exerce papel importante na exocitose dos grânulos secretórios (QUISSELL et al., 1993). Em glândulas submandibulares de coelhos, os subtipos de adrenoceptores $\beta_{1} \mathrm{e}$ 
$\beta_{2}$ são expressos, sendo que subtipo $\beta_{1}$ é predominante e participa da regulação da produção e secreção de amilase (LI et al., 2006). Em células acinares da parótida, a PKA, por sua vez, promove a fosforilação de CREB (cAMP response element binding protein; YAMADA et al., 2006). Ou seja, a estimulação do adrenoceptor $\beta$ de glândulas salivares desencadeia importantes processos como produção e secreção de proteínas salivares.

\subsection{Oadrenoceptor $\beta$}

Os receptores acoplados à proteína G (GPCRs) são extremamente importantes para a sobrevivência de organismos. Aproximadamente $80 \%$ dos hormônios sinalizam por meio destes receptores e cerca de $5 \%$ do genoma humano codifica GPCRs (PEREZ; KARNIK, 2005). Estes receptores possuem 7 domínios transmembranais hidrofóbicos de estrutura $\alpha$-hélice interconectados por alças intracelulares e extracelulares, com a porção C-terminal voltada para o lado intracelular e a porção Nterminal para o lado extracelular. $\mathrm{Na} 2^{\circ}$ e na $3^{\circ}$ alças do domínio intracelular e na parte proximal da região C-terminal, ocorre o acoplamento da proteína G (GETHER, 2000). A proteína $\mathrm{G}$ possui três subunidades $(\mathrm{G} \alpha, \mathrm{G} \beta$ e $\mathrm{G} \gamma)$ que permanecem unidas enquanto a subunidade Ga está ligada a uma molécula de GDP. Quando há a ligação de um agonista, o receptor muda de conformação e acopla-se à proteína G, promovendo sua

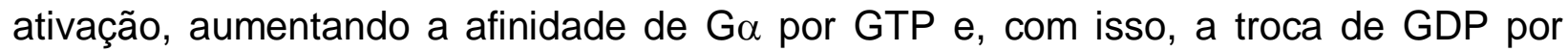
GTP. Isto promove a dissociação das subunidades $\mathrm{G} \alpha$ e $\mathrm{G} \beta \gamma$. Estas subunidades podem, então, desencadear diferentes respostas através da ativação ou inativação de 
várias moléculas, como fosfolipases e proteínas quinases, dentre outras. A subunidade G $\alpha$ possui uma atividade GTPase intrínseca e, por isso, hidrolisa GTP em GDP e volta ao seu estado inativo com a ligação das subunidades $\mathrm{G} \alpha$ e $\mathrm{G} \beta \gamma$ (para revisão sobre proteínas G, ver MALBON, 2005; STROSBERG; NAHMIAST, 2007). A sinalização por meio de proteínas $\mathrm{G}$ é um processo regulado por proteínas reguladoras da sinalização da proteína G (RGSs) que possuem um domínio RGS que se liga diretamente à

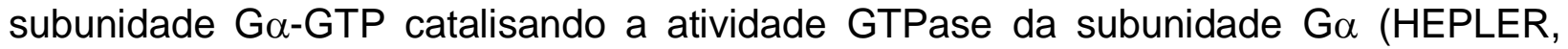
1999). Existem também as quinases de receptores acoplados a proteína G (GRKs), que regulam a atividade das proteínas $G$ por fosforilar o receptor e, dessa forma, dessensibilizá-lo (YANG; XIA, 2006).

Os adrenoceptores $\beta$ (figura 4) são GPCRs e pertencem à subfamília Rhodopsina (FREDRIKSSON et al., 2003). Classicamente, o adrenoceptor $\beta$ se acopla à proteína $\mathrm{G}_{\mathrm{s}}$, que promove a ativação da proteína adenilil ciclase levando à produção de AMPc e, conseqüentemente, à ativação de PKA. Entretanto, quando ocorre a fosforilação do adrenoceptor $\beta$, este pode acoplar-se à proteína $G_{i}$ e, com isso, ativar a fosfolipase $C$ (PLC) por meio da subunidade GßY (LUO et al., 1999; MARTIN et al., 2004; UEZONO et al., 2004). O adrenoceptor $\beta$ pode também exercer suas funções através de outras interações sem a participação da proteína G, dependendo do tipo celular (HALL et al., 1998; PEREZ; KARNIK, 2005), como por exemplo, por meio da interação do fator regulatório do trocador $\mathrm{Na}^{+} / \mathrm{H}^{+}$com a região C-terminal do adrenoceptor $\beta_{2}$ (HALL et al., 1998). 


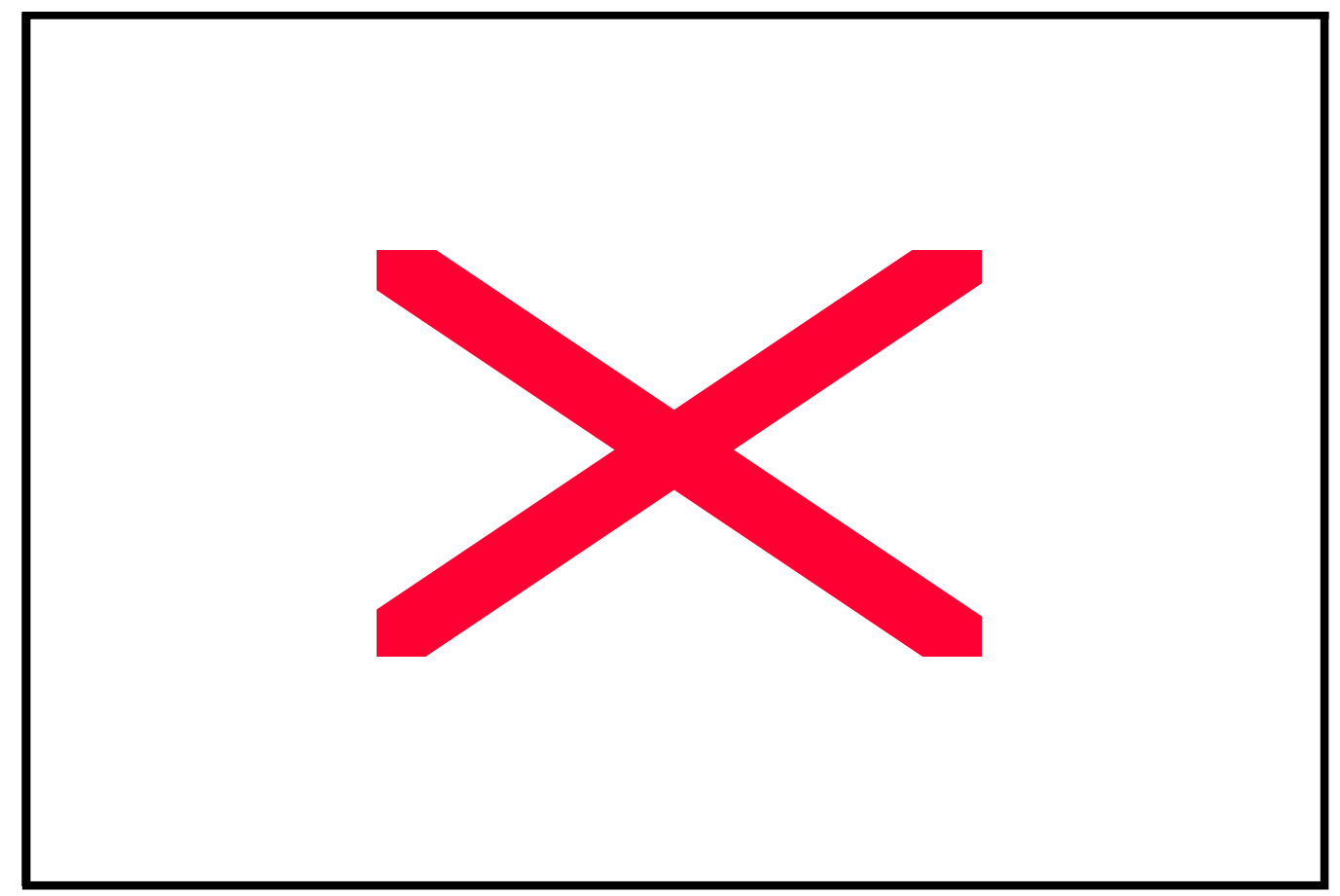

Figura 4: Diagrama representando a estrutura do adrenoceptor $\beta_{2}$ de humanos. (JOHNSON, 1998).

\subsection{1 $O$ adrenoceptor $\beta$ da glândula de veneno de Bothrops jararaca}

$O$ adrenoceptor $\beta$ está presente em glândulas de veneno tanto no estado quiescente como no estado ativado. Este receptor possui um perfil farmacológico diferente dos descritos em mamíferos e com baixa afinidade à ligantes seletivos $\beta_{1}$ (metoprolol), $\beta_{2}$ (ICl118551) e $\beta_{3}$ (BRL 37344, CL316243, SR59230A) (YAMANOUYE et al., 2000) e está acoplado à proteína $\mathrm{G}_{\mathrm{s}}$, visto que sua estimulação aumenta os níveis de AMPc e propranolol, antagonista do adrenoceptor $\beta$, é capaz de bloquear este efeito. Outra característica importante deste adrenoceptor é que após sua estimulação ele sofre dessensibilização, uma vez que o aumento de AMPc produzido por 
isoprenalina só foi obtido em células secretoras quiescentes e não em células secretoras no pico máximo de ativação (4 dias após a extração de veneno). Entretanto, a maquinaria para a produção de AMPc nas células ativadas encontra-se presente, visto que forscolina, droga que estimula diretamente a adenilil ciclase, ainda é capaz de aumentar a produção de $\mathrm{AMPc}$, sugerindo assim que após sua estimulação o adrenoceptor $\beta$ está desacoplado da proteína G. Estes dados sugerem um papel importante do adrenoceptor $\beta$ para o início do ciclo de produção de veneno (YAMANOUYE et al., 2000).

O aumento de AMPc verificado após a estimulação do adrenoceptor $\beta$ em células secretoras da glândula de veneno de Bothrops jararaca não é dependente da dose (YAMANOUYE et al. 2000), mostrando que este adrenoceptor pode estar envolvido com outras vias de sinalização que não somente a via clássica AMPc/Proteína quinase A (PKA).

\subsection{O cálcio}

Um segundo mensageiro de extrema importância para a sinalização celular é o íon cálcio. Devido a sua versatilidade de sinais, esta molécula participa desde sinalizações locais, dentro de uma organela por exemplo, até sinalizações mais globais, como a apoptose celular (BERRIDGE et al., 1999). Por este motivo, os aumentos citosólicos de cálcio são eventos extremamente regulados e a estabilidade é atingida através do balanço entre a entrada e constante remoção deste íon para fora da célula ou para estoques intracelulares (BERRIDGE, 1997). 
Há 2 fontes de íons cálcio que podem ser mobilizadas para promover o aumento de cálcio citosólico: o meio extracelular e estoques intracelulares. O influxo de cálcio a partir do meio extracelular pode ocorrer por meio de diferentes tipos de canais localizados na membrana plasmática. Os canais de cálcio operados por voltagem permitem o influxo de cálcio quando ocorre a despolarização da membrana e, conseqüentemente, a abertura destes canais. Eles podem ser divididos em subtipos: L, N, R e P/Q (CATTERALL et al., 2005). Outros canais que participam do influxo de cálcio são os TRPs (transiente receptor potential), que podem estar funcionalmente associados a GPCRs, receptores tirosina-quinase e PLC. Dentro dos TRPs, há os subtipos TRPC (TRP Clássico) 4 e TRPC 5, que são canais operados por receptores (CLAPHAM; RUNNELS, STRÜBING, 2001; CLAPHAM et al., 2005). Os canais de cálcio operados por estoques (SOCs) também são canais de membrana plasmática e participam da entrada de cálcio após a liberação de cálcio de estoques intracelulares, no entanto, há controvérsias na literatura quanto à classificação deste tipo de canal, sendo alguns deles considerados TRPCs (TRPC 1, TRPC 2, TRPC 3, TRPC 4 e TRPC 5) (CLAPHAM et al., 2005; KAZNACHEYEVA et al., 2007). Há também os canais ativados por nucleotídeo cíclico, que são ativados por AMPc e guanosina monofosfato cíclico (GMPc). Estes canais são mais permeáveis a cátions monovalentes, como sódio e potássio, mas podem permitir a entrada de pequenas quantidades de cálcio. No entanto, o cálcio é também um regulador deste tipo de canal, pois ele diminui a permeabilidade a íons monovalentes e, além disso, se liga à calmodulina, sendo que o complexo cálcio/calmodulina regula negativamente a atividade do canal (HOFMANN; BIEL; KAUPP, 2005; KAUPP; SEIFERT, 2002). Já o aumento intracelular de cálcio proveniente de estoques intracelulares é mediado por 2 tipos principais de canais, os 
receptores de rianodina e os receptores de trifosfato de inositol $\left(\mathrm{IP}_{3}\right)$, sendo ambos encontrados no retículo endoplasmático (BERRIDGE, 1997; 1999; NOWYCKY; THOMAS, 2002). O complexo de Golgi e a mitocôndria também são importantes estoques intracelulares de cálcio, sendo que no Golgi são encontrados receptores de IP $_{3}$ (DOLMAN; TEPIKIN, 2006) e na mitocôndria a liberação de cálcio se dá por meio de trocadores iônicos (GANITKEVICH, 2003).

\subsubsection{O adrenoceptor $\beta$ e o cálcio}

Dados da literatura mostram que a estimulação do adrenoceptor $\beta$ pode levar a um aumento citosólico de cálcio por mecanismo diversos, específicos para cada tipo celular. Em estudo com células do ducto da glândula submandibular de rato, foi verificado que, quando estas células são estimuladas com isoprenalina, ocorre a mobilização de cálcio de estoques intracelulares mediado por AMPc, via fosforilação de receptores de $\mathrm{IP}_{3}$ por PKA (BRUCE et al., 2002; NEZU et al., 2000). No entanto, este aumento é verificado apenas em células de ducto da glândula submandibular e não em células acinares (NEZU et al., 2005). Em miócitos da veia portal de coelho, a estimulação dos adrenoceptores $\beta$ leva a um influxo de cálcio extracelular via canal de cálcio operado por voltagem do tipo $L$ e envolve tanto a subunidade $\alpha$ como a subunidade $\beta \gamma$ da proteína G, através de PKA e PKC, respectivamente (ZHONG, et al., 2001). Em pré-adipócitos marrons de camundongos, foi verificado que a estimulação do adrenoceptor $\beta$ induz um aumento lento na concentração citosólica de cálcio através de AMPc/PKA (DOLGACHEVA et al., 2003). Já em miócitos cardíacos, a estimulação 
do adrenoceptor $\beta$ promove o aumento de cálcio intracelular via AMPc/PKA, através da ativação de canais de cálcio operados por voltagem do tipo $L$ e ativação de receptores de rianodina, ou seja, promove o influxo de cálcio e a liberação de cálcio de estoques intracelulares (ENDOH, 2007). Outra via de sinalização que pode levar a um aumento de cálcio intracelular é mediada pela proteína $G_{i}$, cuja subunidade $\beta \gamma$ pode ativar PLC, que leva a um aumento de $\mathrm{IP}_{3}$ e este, por sua vez, promove a abertura de estoques de cálcio intracelulares (LUO et al., 1999).

Entretanto, há dados na literatura que mostram que a estimulação do adrenoceptor $\beta$ pode também inibir o aumento de cálcio intracelular, como ocorre em células de músculo liso de corpos cavernosos de coelhos (SATO; KAWATANI, 2002). Em células cromafins da medula adrenal, o cálcio participa do processo de exocitose por controlar a fusão de grânulos de secreção, no entanto, a estimulação do adrenoceptor $\beta$ bloqueia o influxo de cálcio mediado por de canais de cálcio do tipo L. Ou seja, nestas células o adrenoceptor $\beta$ é um regulador do processo de exocitose (POLO-PARADA et al., 2006).

\subsection{Relevância}

Dados sobre o adrenoceptor $\beta$ da glândula de veneno sugerem um papel importante para o início do ciclo de produção de veneno. Portanto, sua caracterização funcional durante o ciclo de produção de veneno é de suma importância para a compreensão dos mecanismos celulares envolvidos na produção de veneno e para o entendimento da dinâmica da glândula de veneno. Este estudo tem sua relevância no 
âmbito dos estudos comparativos, bem como na obtenção de uma linhagem de células secretoras funcionais, que secretem veneno com atividade biológica semelhante ao veneno extraído da serpente. 


\section{OBJETIVO}

O objetivo deste estudo é caracterizar funcionalmente o adrenoceptor $\beta$ presente na glândula de veneno da serpente Bothrops jararaca, durante o ciclo de produção de veneno, bem como verificar o papel deste adrenoceptor na produção e secreção de veneno.

Para atingir este objetivo, iremos:

- Verificar se a estimulação do adrenoceptor $\beta$ desencadeia mudanças na taxa de acidificação do meio extracelular em células secretoras em diferentes estados de ativação.

- Verificar se a estimulação do adrenoceptor $\beta$ promove aumento de cálcio citosólico em células secretoras quiescentes e ativadas por 4 dias, além de verificar quais as vias e canais envolvidos nesta sinalização.

- Verificar, in vivo, o papel do adrenoceptor $\beta$ na produção de veneno. 


\section{MATERIAIS E MÉTODOS}

\subsection{Reagentes}

- $\quad$ (-)-Hidrocloreto de propranolol: Sigma Chem. Co., St. Louis, MO, USA

- $\quad(-)-$ Isoproterenol bitartrate: Sigma Chem. Co., St. Louis, MO, USA

- $\quad$ Ácido Plurônico F-127: Sigma Chem. Co., St. Louis, MO, USA

- $\quad$ Azul de Tripan (solução 0,4\%): Sigma Chem. Co., St. Louis, MO, USA

- $\quad$ Colagenase: Worthington Biochem. Co., Lakewood, NJ, USA

- Digitonina: ICN Biomedicals Inc., Aurora, Ohio, USA

- $\quad$ Diltiazem: gentilmente cedido por Boehringer De Angeli, Brasil

- Fura-2-acetoxymethyl Ester (Fura-2/AM): Calbiochem, La Jolla, CA, USA

- Hialuronidase: Sigma Chem. Co., St. Louis, MO, USA

- Meio de cultura: Dulbecco's Modified Eagle Medium (DMEM), Gibco, Rockville, MD, USA

- Pentobarbital sódico: Cristália, São Paulo, SP, Brasil

- $\quad$ Protein Kinase A Inhibitor 14-22 Amide, Cell-Permeable, Myristoylated (PKI): Calbiochem, La Jolla, CA, USA

- Reserpina cristalina: Sigma Chem. Co., St. Louis, MO, USA

- Resina Epon 812: Electron Microscopy Sciences, Hatfield, PA, USA

- $\quad$ SKF 96365, hydrochloride: Calbiochem, La Jolla, CA, USA

- Solução de antibiótico e anti-fúngico: (Antibióticos: penicilina e estreptomicina e anti-fúngico: Anfotericina B), Gibco, Rockville, MD, USA 
- $\quad$ Soro Fetal Bovino: Gibco, Rockville, MD, USA

- $\quad$ Tapsigargina: Sigma Chem. Co., St. Louis, MO, USA

Todos os demais sais e reagentes utilizados para preparação de líquidos nutritivos e tampões foram provenientes da MERCK (Alemanha) ou Sigma Chem. Co. (USA).

\subsection{Tampões e solucões}

- Solução fisiológica Krebs-Hepes: $\mathrm{NaCl} 120 \mathrm{mM}, \mathrm{KCl} 4 \mathrm{mM}, \mathrm{MgSO}_{4}$ 1,2 mM, $\mathrm{KH}_{2} \mathrm{PO}_{4} 1,2 \mathrm{mM}$, HEPES $15 \mathrm{mM}$ e glicose $10 \mathrm{mM}, \mathrm{pH} 7,4$.

- Solução estoque de isoprenalina: 0,01 M em solução fisiológica Krebs-Hepes.

- Solução estoque de pluronic: $20 \%$ em dimetilsulfoxido (DMSO).

- Solução estoque de digitonina: 5 mM em DMSO.

- Solução estoque de propranolol: 0,01 M em Krebs-Hepes.

- Solução estoque de Inibidor de PKA (PKI): 0,4 M em água deionizada.

- Solução estoque de $\mathrm{MnCl}_{2}: 0,2 \mathrm{M}$ em água deionizada.

- Solução estoque de Diltiazem: 0,01 M em água deionizada.

- Solução estoque de Tapsigargina: 1 mM em água deionizada.

- Solução fixadora (microscopia eletrônica): solução de aldeído glutárico 1,5\% com paraformaldeído 1\% em tampão cacodilato de sódio 0,1 M.

- Solução pós-fixadora (microscopia eletrônica): Tetróxido de ósmio $1 \%$ em tampão cacodilato de sódio $0,1 \mathrm{M}$. 
- Solução uranila (microscopia eletrônica): acetato de uranila 0,5\%, sacarose $13,3 \%$.

- Tampão de lavagem (microscopia eletrônica): $\mathrm{NaCl}$ 0,9\%, sacarose 1,78\%.

\section{$\underline{3.3 \quad \text { Animais }}$}

Serpentes Bothrops jararaca $(n=94)$ adultas $(100-400 \mathrm{~g})$ de ambos os sexos, vindas da natureza e classificadas no Laboratório de Herpetologia do Instituto Butantan, foram tratadas e mantidas em sala com condições ambientais controladas, segundo Breno et al. (1990): fotoperíodo de 12 horas, temperatura entre 21 e $27^{\circ} \mathrm{C}$ e umidade relativa de aproximadamente $65 \%$. As serpentes não tiveram acesso à comida por 40 dias, período necessário para evitar a perda de veneno e garantir que as células estivessem no estágio quiescente (não ativadas). Serpentes podem ficar sem se alimentar por 1 ou 2 meses, sendo que este período pode se estender por até um ano na natureza (SECOR; NAGY, 1994).

Os procedimentos experimentais estão de acordo com o Colégio Brasileiro de Experimentação Animal (COBEA) e foram aprovados pela Comissão de Ética no Uso de Animais do Instituto Butantan (CEUAIB) e pela Comissão de Ética em Experimentação Animal do Instituto de Ciências Biomédicas - USP.

\subsection{Funcionalidade do adrenoceptor $\beta$ durante o ciclo de producão de veneno}




\subsubsection{Glândula de veneno}

Utilizamos glândulas de veneno de serpentes que não sofreram extração de veneno, ou seja, com as glândulas de veneno no estado quiescente, e de serpentes que sofreram extração de veneno 4 ou 15 dias antes do sacrifício, ou seja, com glândulas de veneno ativadas por 4 ou 15 dias. As serpentes foram previamente anestesiadas com pentobarbital sódico (30 mg/ kg, s.c.), decapitadas e as glândulas de veneno foram coletadas e dissecadas, como descrito por Yamanouye et al. (2007). Para a extração manual de veneno (BELLUOMINI, 1968) as serpentes foram anestesiadas com pentobarbital sódico (20 mg/kg, s.c.). A cada experimento foram utilizadas glândulas de veneno de 2 serpentes.

\subsubsection{Dispersão de células secretoras de glândula de veneno}

A dispersão de células secretoras foi baseada no método descrito por Kerchove et al. (2004) e Yamanouye et al. (2007). As glândulas de veneno, após a dissecação, foram cortadas em fatias de $250 \mu \mathrm{m}$ (Mcllwain Tissue chopper - Brinkmann) e as células secretoras foram dispersas em solução fisiológica estéril de Krebs-Hepes contendo colagenase $(3 \mathrm{U} / \mathrm{mg}$ de tecido úmido), hialuronidase $(3,5 \mathrm{U} / \mathrm{mg}$ de tecido úmido), antibióticos e anti-micótico (respectivamente $100 \mathrm{U} / \mathrm{ml}$ de penicilina e $100 \mu \mathrm{g} / \mathrm{ml}$ de estreptomicina e $0,25 \mu \mathrm{g} / \mathrm{ml}$ de anfotericina B) por 90 minutos em temperatura ambiente sob agitação constante. Durante este período foi feita também dispersão mecânica, que consistiu em sucessivas pipetagens feitas a períodos regulares (30 
minutos, 45 minutos e 60 minutos após o início da dispersão enzimática). Logo após, as células foram centrifugadas (10 minutos a $1000 \mathrm{~g}$ ) e ressuspensas em meio DMEM (Dulbeco's Modified Eagle Medium) acrescido de bicarbonato de sódio (3,7 g/l) e antibióticos e anti-micótico (respectivamente $100 \mathrm{U} / \mathrm{ml}$ de penicilina e $100 \mu \mathrm{g} / \mathrm{ml}$ de estreptomicina e $0,25 \mu \mathrm{g} / \mathrm{ml}$ de anfotericina B). Para separar as células secretoras do tecido conjuntivo, foi feita a filtração destas células em malha de nylon e depois foram feitas mais 2 lavagens para assegurar a total remoção das enzimas. A contagem das células foi feita na presença de azul de tripan (solução de $0,4 \%$ ) e as células dispersas viáveis foram mantidas por até 2 dias em placa de 24 poços ( 2 a $3 \times 10^{6}$ células/poço) em meio DMEM com bicarbonato de sódio $(3,7 \mathrm{~g} / \mathrm{l})$, antibióticos (100 U/ml de penicilina e $100 \mu \mathrm{g} / \mathrm{ml}$ de estreptomicina) e 10\% de FBS (Soro Fetal Bovino) em incubadora de $\mathrm{CO}_{2}(5 \%)$ a $30^{\circ} \mathrm{C}$.

\subsubsection{Medida da taxa de acidificação extracelular por microfisometria em células secretoras da glândula de veneno}

A taxa de acidificação extracelular foi determinada através da utilização do microfisiômetro (Cytosensor ${ }^{\circledR}$ Microphysiometry, Molecular Devices, Menlo Park, CA). O microfisiômetro utiliza um sensor potenciométrico estimulado por um diodo emissor de luz (LED) para medir a acidificação do meio decorrente do aumento de metabolismo celular. Essa metodologia já foi empregada para a caracterização do adrenoceptor $\alpha$ de células secretoras de veneno da serpente Bothrops jararaca (KERCHOVE et al., 2004). As células secretoras dispersas $\left(0,5\right.$ a $\left.1 \times 10^{6}\right)$ foram aderidas a uma membrana 
permeável de poli-carbonato através de uma suspensão em agarose $30 \%$. Essas células foram perfundidas com meio DMEM (complementado com 2,59 g/l de $\mathrm{NaCl}$ para ajuste da osmolaridade e $0,1 \mathrm{~g} / \mathrm{l}$ de ácido ascórbico, $\mathrm{pH} 7,4)$ a $30^{\circ} \mathrm{C}$, através de uma bomba peristáltica com fluxo de $100 \mu \mathrm{l} / \mathrm{min}$. A bomba seguiu um padrão de estágio ligado e desligado com um ciclo de 3 minutos, sendo 2 min e 20 s como bomba ligada e 40s como bomba desligada. Durante a fase de bomba ligada, o $\mathrm{pH}$ do meio atinge um valor constante de acidificação devido à renovação do meio na câmara de células. No período de bomba desligada, o meio acidifica pelo acúmulo de prótons excretados pelas células, indicativo de metabolismo celular. Dessa maneira, a velocidade de acidificação extracelular foi determinada pela medida da inclinação (coeficiente angular) da reta de queda do $\mathrm{pH}$ durante o período de bomba desligada através do programa Cytosoft (Molecular Devices, Menlo Park, CA).

Após a estabilização da preparação (45 min), doses crescentes de isoprenalina $\left(10^{-9}\right.$ a $\left.10^{-2} \mathrm{M}\right)$ foram adicionadas a cada 30 minutos. Foram realizadas curvas concentração-resposta à isoprenalina em células secretoras dispersas de glândulas de veneno no estágio quiescente, ativado por 4 dias ou ativado por 15 dias. As curvas foram ajustadas através de uma regressão não linear e o valor de $\mathrm{pD}_{2}\left(-\log E \mathrm{C}_{50}\right)$ calculado de acordo com o programa Graph-Pad Prism (San Diego, CA).

\subsubsection{Medida de cálcio citosólico em células secretoras por fluorimetria}

As células dispersas quiescentes ou ativadas por 4 dias $\left(2\right.$ a $\left.3 \times 10^{6}\right)$ foram ressuspensas em Krebs-Hepes adicionado de ácido ascórbico $(0,1 \mathrm{~g} / \mathrm{l})$ e incubadas 
com $2 \mu \mathrm{M}$ de fura-2 acetoximetil ester (fura-2/AM) na presença de 0,04\% de ácido plurônico F-127 para aumentar a solubilidade do fura-2/AM, por 2 horas em temperatura ambiente, sob agitação constante. Logo após, as células foram lavadas, centrifugadas (1000 g, 10 min.), ressuspensas em solução Krebs-Hepes acrescida de cálcio $(2,5 \mathrm{mM})$ ou em solução Krebs-Hepes nominalmente sem cálcio e colocadas em cubetas de quartzo. Em seguida, as células foram colocadas no fluorímetro (PTI Photon Technology International, Birminghan, NJ, USA) e alternadamente excitadas em comprimentos de onda de 340 e $380 \mathrm{~nm}$. As intensidades de fluorescências emitidas foram medidas em $510 \mathrm{~nm}$. Dentro da célula, o fura-2/AM é hidrolisado e transforma-se em fura-2, que se complexa ao cálcio livre no citosol. O complexo cálcio/fura-2 é excitado no comprimento de onda $340 \mathrm{~nm}$, enquanto o fura-2 livre é excitado em 380 nm. Ambos emitem fluorescência máxima no comprimento de onda $510 \mathrm{~nm}$. Para a análise dos resultados obtidos, os valores foram apresentados como a razão da fluorescência obtida em ambas excitações ( $R$ 340/380), que foi calculada através do programa Felix ${ }^{\mathrm{TM}}$ Software (PTI - Photon Technology International, Birminghan, NJ, USA). Os valores obtidos foram normalizados em relação à razão de fluorescência basal, fixada em 1. Em seguida os dados foram analisados utilizando o programa Kaleida Graph 3.0 (Synergy Software, Reading, PA, USA). Os valores foram expressos em porcentagem em relação à fluorescência basal.

Durante o experimento foram aplicadas concentrações crescentes de isoprenalina $\left(10^{-6}\right.$ a $\left.3 \times 10^{-4} \mathrm{M}\right)$. O tempo entre as doses do agonista foi determinado conforme a estabilização do aumento de cálcio citosólico promovido. A validação do experimento foi realizada com a adição de digitonina $(0,1 \mathrm{mM})$, droga que permeabiliza membranas 
promovendo um aumento máximo de fluorescência, seguida da adição de $\mathrm{MnCl}_{2}$ (2 $\mathrm{mM}$ ), cuja alta afinidade pelo fura-2 promove o deslocamento do cálcio complexado com o fura-2. Para verificar o mecanismo pelo qual isoprenalina promove aumento de cálcio citosólico, as células foram incubadas por 30 minutos com inibidor de PKA (PKI -

Protein Kinase A Inhibitor 14-22 Amide, Cell Permeable, Myristoylated, $10^{-6} \mathrm{M}$ ), com diltiazem $\left(10^{-5} \mathrm{M}\right)$, inibidor de canais de cálcio operados por voltagem do tipo $L$ ou ainda com SKF $96365(50 \mu \mathrm{M})$, inibidor de canais de cálcio ativados por receptor. Estas células foram também incubadas com tapsigargina $(2 \mu \mathrm{M})$ com o intuito de depletar os estoques intracelulares de cálcio sensíveis a tapsigargina.

\subsection{Estudo in vivo da participação do adrenoceptor $\beta$ na producão de veneno}

Para o estudo da participação do adrenoceptor $\beta$ na produção de veneno foram feitos 2 grupos experimentais. No primeiro grupo, as serpentes foram tratadas com reserpina (20 mg/kg, s.c.) 24 horas antes da extração de veneno e nos 13 dias subsequentes foi administrado reserpina ( $5 \mathrm{mg} / \mathrm{kg}$, s.c., dose de manutenção). No segundo grupo, as serpentes foram tratadas como o primeiro grupo, mas recebendo uma dose de isoprenalina (100 mg/kg, s.c.) logo após a extração de veneno. Após o tratamento, as serpentes foram anestesiadas e sacrificadas e suas glândulas de veneno foram removidas para análise morfológica. 


\subsubsection{Microscopia eletrônica}

As glândulas de veneno foram colocadas em uma gota de solução fixadora sobre uma placa de cera, onde foram seccionadas em pequenos fragmentos com cerca de $1 \mathrm{~mm}^{3}$, que foram deixados em solução fixadora overnight. Após lavagem em tampão específico, os fragmentos foram transferidos para solução pós-fixadora durante 1 hora em temperatura ambiente e lavados novamente com tampão de lavagem e, então, foram deixados em solução de uranila overnight. Os fragmentos foram desidratados em série etanólica e passagem por óxido de propileno. A pré-embebição foi feita em resina Epon com óxido de propileno 1:1, por 2 horas com agitação e, em seguida, em resina Epon com óxido de propileno 1:2, overnight com agitação. Os fragmentos ficaram, então, em resina Epon pura por 2 horas, sob agitação e logo após foram incluídos em resina Epon em formas apropriadas e mantidos por 48 horas a temperatura de $60^{\circ} \mathrm{C}$ em estufa, para polimerização da resina. Cortes ultrafinos $(70 \mathrm{~nm})$ obtidos em ultramicrótomo (Sorvall MT 6000, Thermo Fisher Scientific Inc., Waltham, MA, USA) foram micrografados em microscópio eletrônico de transmissão (LEO 906 E, Zeiss, Thornwood, NY, USA).

\subsection{Análise estatística}

Os resultados foram expressos como Média \pm EPM. A comparação entre duas médias foi feita pelo teste "t" de Student. Foi aceito como significante $p<0,05$. 


\section{RESULTADOS}

O adrenoceptor $\beta$ está presente em glândulas de veneno no estado quiescente $\mathrm{e}$ no estado ativado e possui um importante papel no ciclo de produção de veneno da serpente Bothrops jararaca. Sua estimulação leva à ativação da adenilil ciclase e, conseqüentemente, a um aumento de $\mathrm{AMPc}$ somente em células quiescentes e não em células ativadas (YAMANOUYE et al., 2000), sugerindo sua importância no desencadeamento do ciclo de produção de veneno. Com isso, tornou-se interessante verificar se o adrenoceptor $\beta$ estaria funcional durante o ciclo de produção de veneno, ativando outras vias de sinalização.

\subsection{A estimulacão do adrenoceptor $\beta$ promove aumento da taxa de acidificacão do meio extracelular}

Para verificar a funcionalidade do adrenoceptor $\beta$, empregamos a técnica de microfisiometria, que permite inferir no metabolismo celular através da medida da taxa de acidificação do meio extracelular. Utilizamos células secretoras quiescentes, ativadas por 4 dias ou ativadas por 15 dias com o intuito de acompanhar a funcionalidade deste receptor ao longo do ciclo de produção de veneno.

Isoprenalina $\left(10^{-7}\right.$ a $\left.10^{-2} \mathrm{M}\right)$ promoveu um aumento dependente da dose na taxa de acidificação do meio extracelular, tanto em células quiescentes $\left(\mathrm{pD}_{2}=3,92 \pm 0,17\right.$, $\mathrm{n}=6)$ quanto em células ativadas por 4 dias $\left(\mathrm{pD}_{2}=3,68 \pm 0,27, \mathrm{n}=4\right)$ (figura 5) de maneira similar $(p>0,05)$. Propranolol, antagonista do adrenoceptor $\beta$, foi capaz de inibir totalmente esta resposta (dados não mostrados). Já em células ativadas por 15 dias, 
isoprenalina $\left(10^{-9}\right.$ a $\left.10^{-2} \mathrm{M}\right)$ promoveu um aumento na taxa de acidificação do meio extracelular de maneira não dependente da dose $(15,56 \pm 2,47 \%, n=3$, dados não mostrados). 


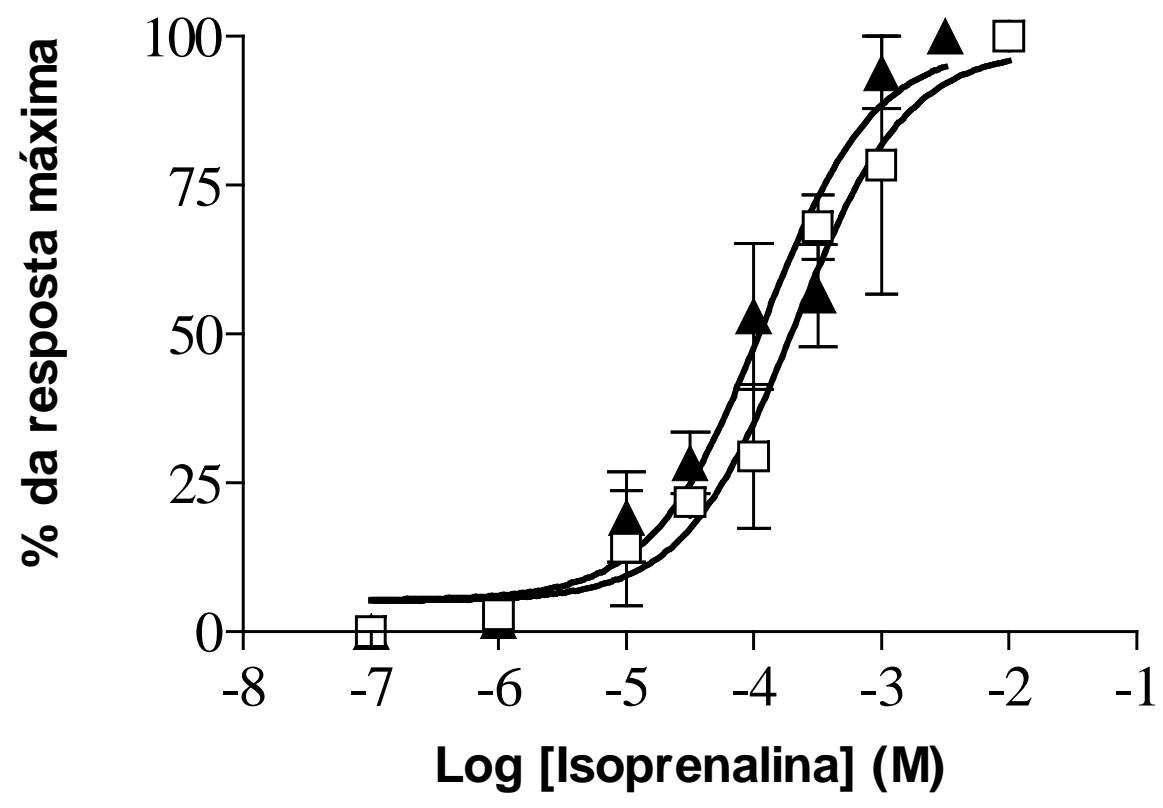

Figura 5: Aumento da taxa de acidificação do meio extracelular promovido por doses crescentes de isoprenalina em células secretoras quiescentes $(\boldsymbol{\Lambda}, n=6)$ e em células secretoras ativadas por 4 dias $(\square, n=4)$. Cada ponto representa média $\pm E P M$. 


\subsection{Isoprenalina induz aumento lento da concentracão de cálcio citosólico em células secretoras}

A estimulação do adrenoceptor $\beta$ presente nas células secretoras da glândula de veneno da serpente Bothrops jararaca leva a um aumento da produção de AMPc em células quiescentes (YAMANOUYE et al, 2000). Como o AMPc promove a ativação de PKA e este é capaz de ativar canais de cálcio (BRUCE et al., 2002), tornou-se interessante verificar se o estímulo do adrenoceptor $\beta$ seria capaz de levar a um aumento de cálcio citosólico.

Em células quiescentes, isoprenalina $\left(3 \times 10^{-6}\right.$ a $\left.3 \times 10^{-4} \mathrm{M}\right)$ foi capaz de aumentar a concentração citosólica de cálcio de maneira dependente da dose. Em células em meio com cálcio $(2,5 \mathrm{mM})$, o aumento da concentração citosólica de cálcio na maior dose ulitizada $(57,38 \pm 8,69 \%, n=7$, figura $6 a)$ foi significativamente maior $(p<0,05)$ do que em células em meio nominalmente cálcio $(20,88 \pm 7,54 \%, n=7$, figura $6 b)$.

Já em células ativadas por 4 dias, isoprenalina promoveu um aumento significativamente menor na concentração citosólica de cálcio do que em células quiescentes $(p<0,05)$. Em meio com cálcio $(2,5 \mathrm{mM})$ o aumento máximo obtido com a maior dose usada foi de $18,16 \pm 0,83 \%$ ( $n=3$, figura $7 a$ ) e em meio nominalmente sem cálcio, o aumento máximo obtido foi de $7,50 \pm 1,60 \%$ ( $\mathrm{n}=3$, figura $7 \mathrm{~b})$.

O intervalo entre a aplicação das doses foi de aproximadamente 10 a 20 minutos, período necessário para que a resposta alcançasse o platô. 


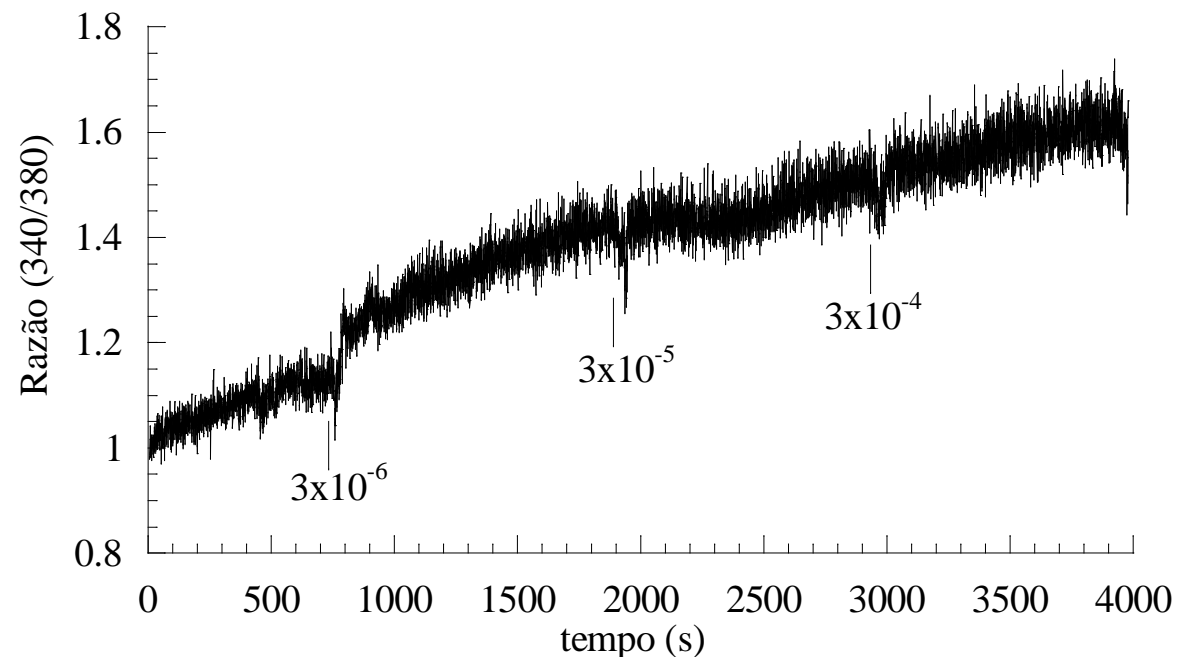

b

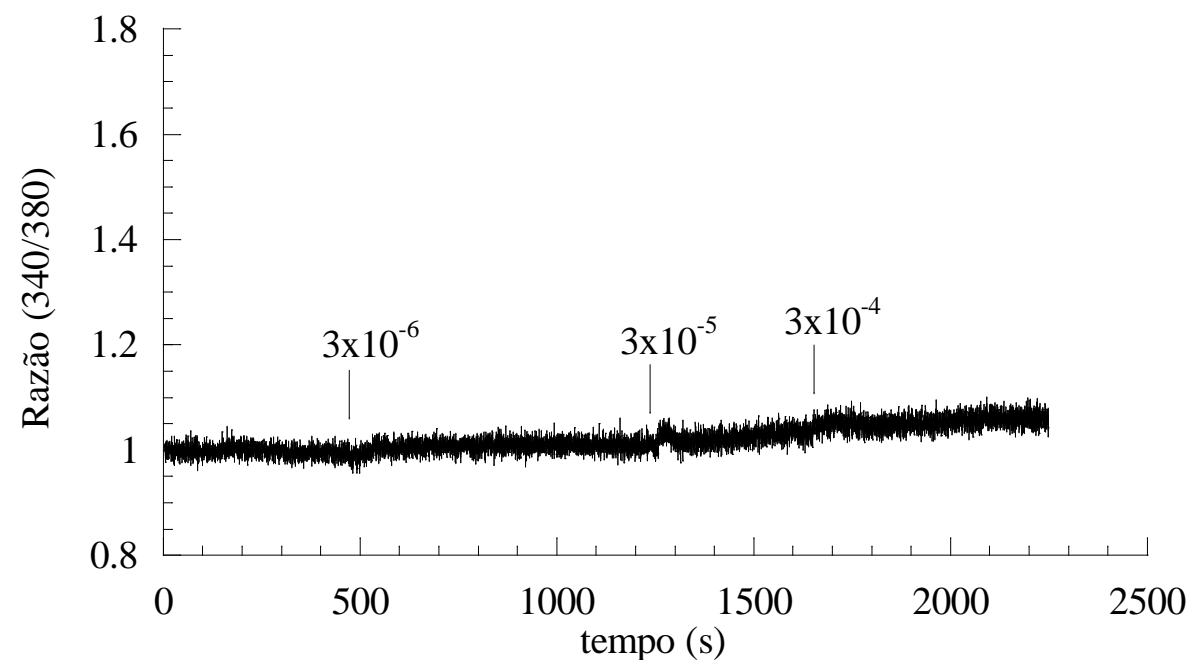

Figura 6: Gráficos representativos do aumento de cálcio citosólico promovido por isoprenalina (doses indicadas no gráfico) em células secretoras quiescentes da glândula de veneno da serpente Bothrops jararaca. a:células em solução KrebsHepes com $2,5 \mathrm{mM}$ de cálcio $(57,38 \pm 8,69 \%, \mathrm{n}=7)$. b: células em solução KrebsHepes nominalmente sem cálcio $(20,88 \pm 7,54 \%, n=7)$. 
a

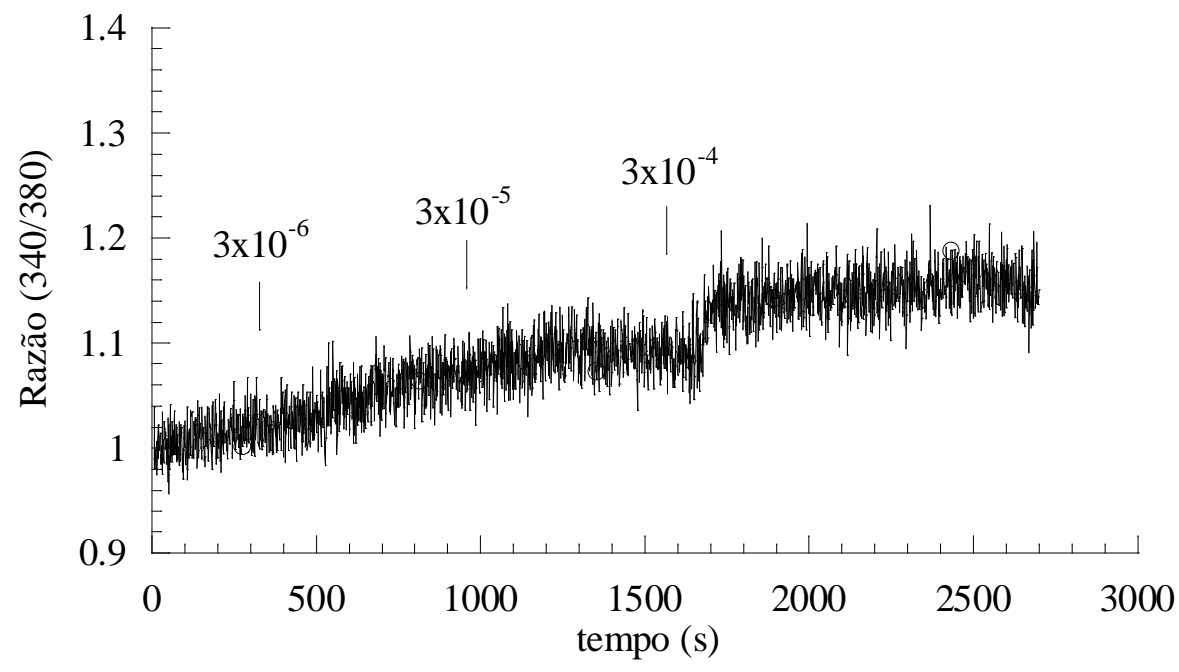

b

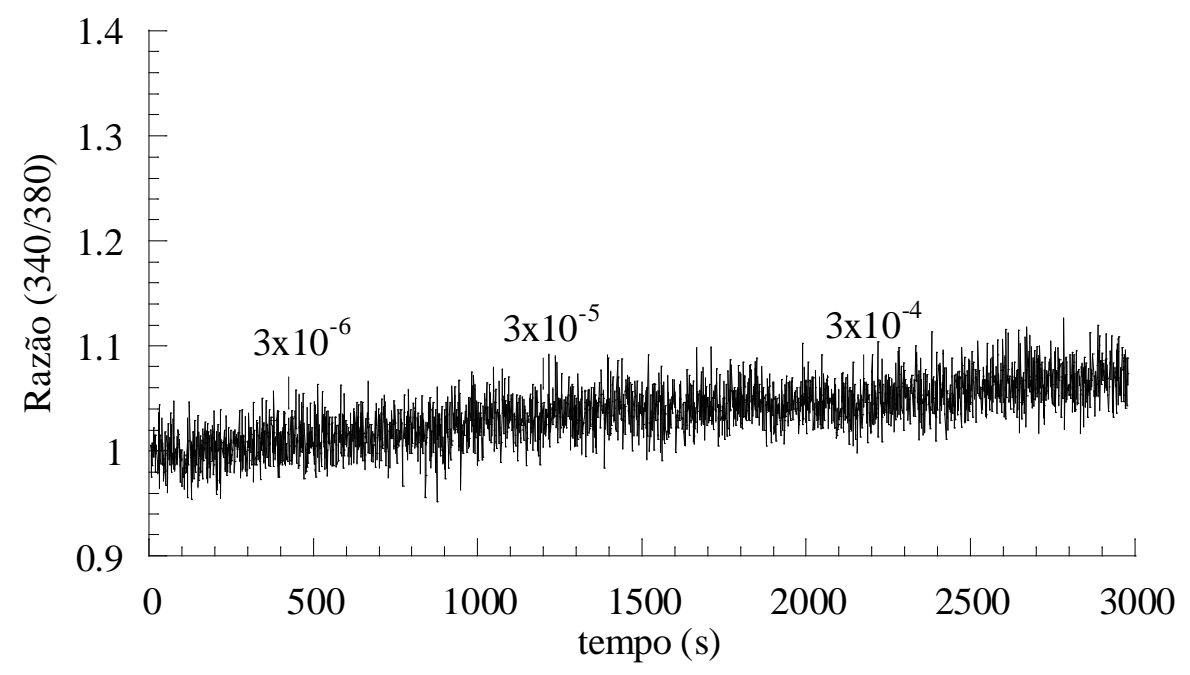

Figura 7: Gráficos representativos do aumento de cálcio citosólico promovido por isoprenalina (doses indicadas no gráfico) em células secretoras da glândula de veneno de Bothrops jararaca ativadas por 4 dias. a: células em solução KrebsHepes com $2,5 \mathrm{mM}$ de cálcio $(18,16 \pm 0,83 \%, n=3)$. $\mathbf{b}$ : células em solução Krebs Hepes nominalmente sem cálcio. $(7,50 \pm 1,60 \%, n=3)$. 


\subsection{Canais de cálcio operados por voltagem e operados por receptor participam da sinalização promovida por isoprenalina}

Com o intuito de verificar quais canais de cálcio estariam participando do aumento de cálcio citosólico desencadeado por isoprenalina em células quiescentes, foi utilizado diltiazem, um inibidor de canais de cálcio operados por voltagem do tipo L. Células secretoras dispersas foram incubadas com diltiazem $\left(10^{-5} \mathrm{M}\right)$ por 30 minutos antes do início do registro do experimento, em meio com cálcio $(2,5 \mathrm{mM})$. Nestas células, isoprenalina $\left(3 \times 10^{-6}\right.$ a $\left.3 \times 10^{-4} \mathrm{M}\right)$ foi capaz de aumentar a concentração de cálcio citosólico $(29,88 \pm 3,25 \%, n=7$, figura 8$)$, entretanto, este aumento foi significantemente menor $(p<0,05)$ do que em células não incubadas com diltiazem (figura 6a), indicando a participação de canais de cálcio operados por voltagem do tipo L no aumento de cálcio citosólico promovido por isoprenalina.

Como diltiazem não foi capaz de inibir totalmente o aumento de cálcio promovido por isoprenalina, foi utilizado SKF 96365, um inibidor de canais de cálcio operados por receptor. Em células secretoras quiescentes em meio com cálcio $(2,5 \mathrm{mM})$ incubadas por 30 minutos com SKF $96365\left(3 \times 10^{-5} \mathrm{M}\right)$, verificou-se que o aumento máximo de cálcio citosólico promovido pela maior dose de isoprenalina usada foi significativamente menor $(5,21 \pm 0,67 \%, n=4$, figura 9) do que em células não incubadas com SKF 96365 (figura $6 a, p<0,05$ ), indicando que canais de cálcio operados por receptor também participam do aumento de cálcio intracelular promovido por isoprenalina. 


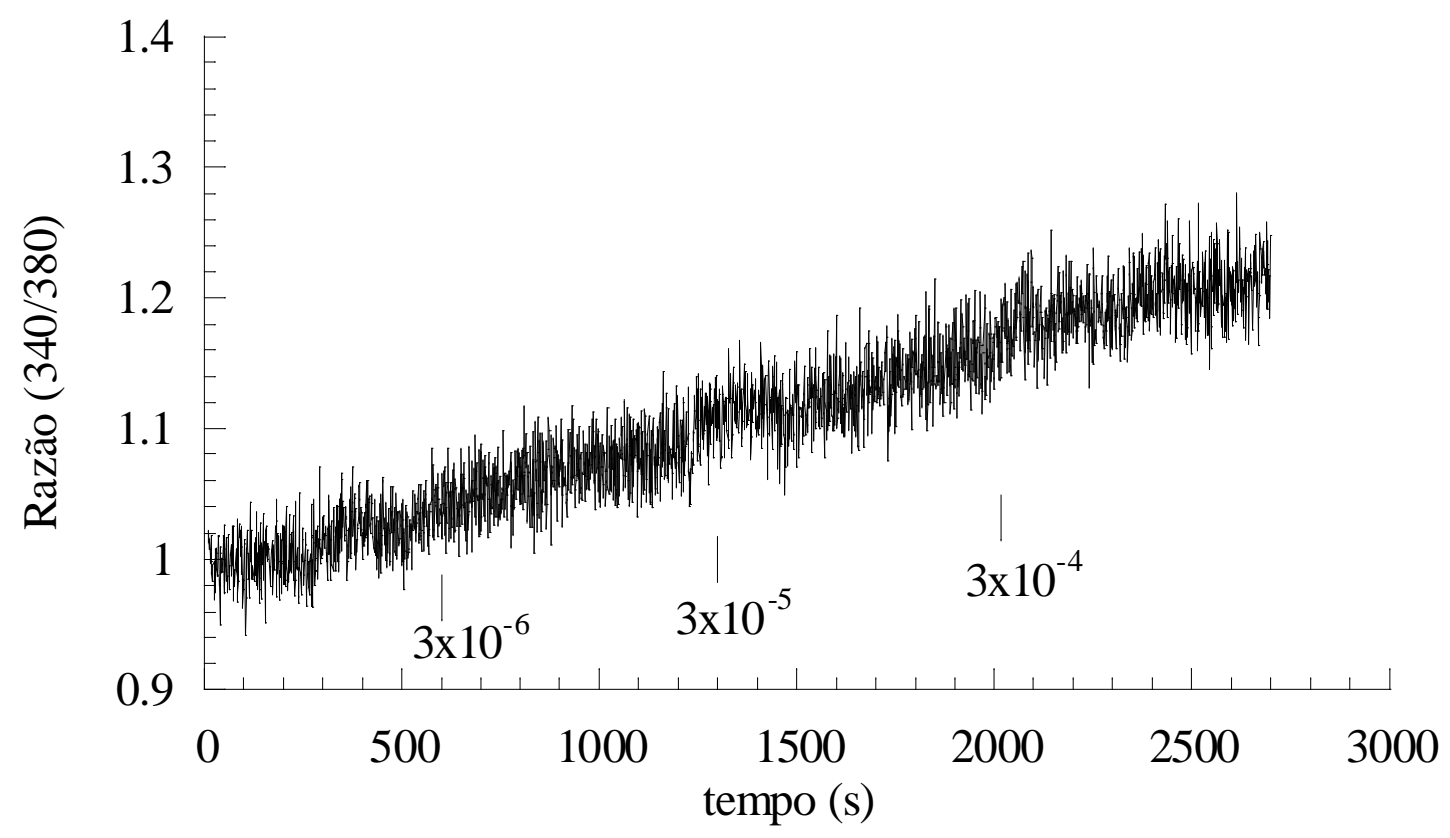

Figura 8: Gráfico representativo do aumento de cálcio citosólico $(29,88 \pm 3,25 \%, n=7)$ promovido por isoprenalina (doses indicadas no gráfico) em células secretoras quiescentes da glândula de veneno de Bothrops jararaca previamente incubadas por 30 minutos com diltiazem $\left(10^{-5} \mathrm{M}\right)$ em solução Krebs-Hepes com cálcio $(2,5 \mathrm{mM})$. 


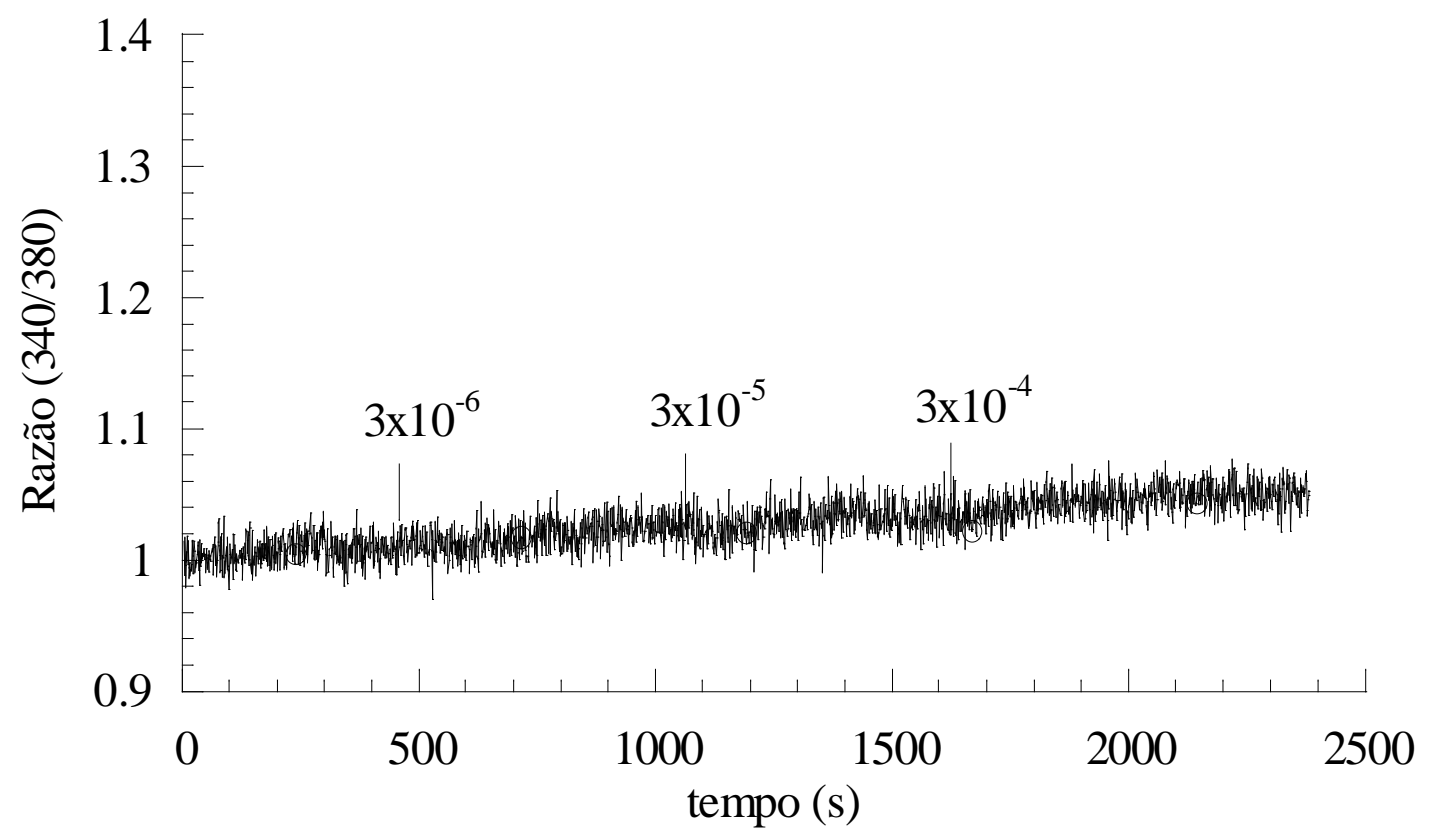

Figura 9: Gráfico representativo do aumento de cálcio citosólico $(5,21 \pm 0,67 \%, n=4)$ promovido por isoprenalina (doses no gráfico) em células secretoras quiescentes da glândula de veneno de Bothrops jararaca, previamente incubadas por 30 minutos com SKF 96365 (50 $\mu \mathrm{M})$ em solução Krebs-Hepes com cálcio (2,5mM). 


\subsection{Canais de cálcio sensíveis a tapsigargina participam da sinalizacão promovida por isoprenalina}

A estimulação do adrenoceptor $\beta$ pode levar à ativação da proteína $\mathrm{G}_{\mathrm{i}}$, que, através da subunidade G $\beta \gamma$, pode levar à ativação de PLC (LUO et al., 1999; UEZONO et al., 2004). Este, por sua vez, promove o aumento na concentração de $I P_{3}$, que pode desencadear um aumento de cálcio citosólico através da mobilização de cálcio de estoques intracelulares, como o retículo endoplasmático (LUO et al., 1999)

Para verificar quais estoques de cálcio estariam participando da sinalização desencadeada pela estimulação do adrenoceptor $\beta$ em células secretoras quiescentes em meio nominalmente sem cálcio, as células secretoras foram incubadas com tapsigargina (2 $\mu \mathrm{M})$, droga que bloqueia a bomba cálcio-ATPase do retículo endoplasmático levando a depleção dos estoques de cálcio sensíveis a tapsigargina. Após a estabilização da fluorescência, isoprenalina $\left(3 \times 10^{-5}\right.$ e $\left.3 \times 10^{-4} \mathrm{M}\right)$ ainda promoveu aumento da concentração citosólica de cálcio $(6,49 \pm 1,9 \%, n=3$, figura 10), entretanto esse aumento foi significantemente menor do que em células não incubadas com tapsigargina (figura 6b), indicando a participação de cálcio de estoques sensíveis a tapsigargina na sinalização desencadeada pelo adrenoceptor $\beta$ de células secretoras da glândula de veneno de Bothrops jararaca. 


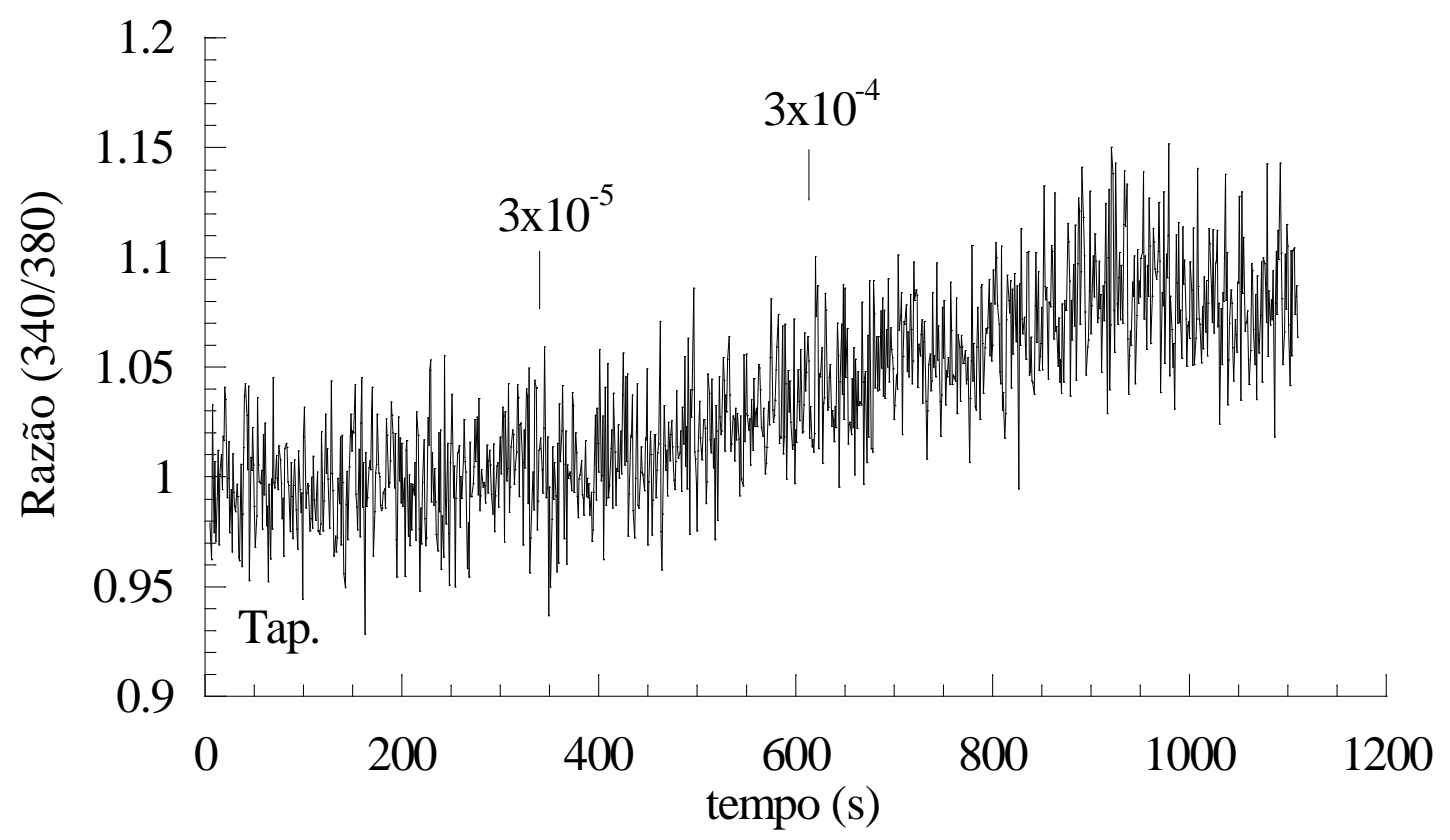

Figura 10: Gráfico representativo do aumento de cálcio citosólico $(6,49 \pm 1,9 \%, n=3)$ promovido por isoprenalina (doses indicadas no gráfico) em células secretoras quiescentes da glândula de veneno de Bothrops jararaca incubadas com tapsigargina $(2 \mu \mathrm{M})$ em solução Krebs-Hepes nominalmente sem cálcio. 


\subsection{Propranolol desencadeia aumento de cálcio intracelular}

Propranolol é um antagonista clássico não seletivo do adrenoceptor $\beta$ e foi utilizado com sucesso na inibição da produção de AMPc (YAMANOUYE et al., 2000) e também na inibição do aumento da taxa de acidificação do meio extracelular em células secretoras da glândula de veneno de Bothrops jararaca. Com o intuito de confirmar a participação do adrenoceptor $\beta$ no aumento de cálcio citosólico promovido por isoprenalina, células secretoras dispersas foram incubadas com propranolol $\left(10^{-4}\right.$ M) por 30 minutos antes do início do experimento. Os resultados obtidos mostraram que propranolol foi capaz de, por si só, desencadear um aumento crescente de cálcio citosólico ( $n=3$, figura 11). 


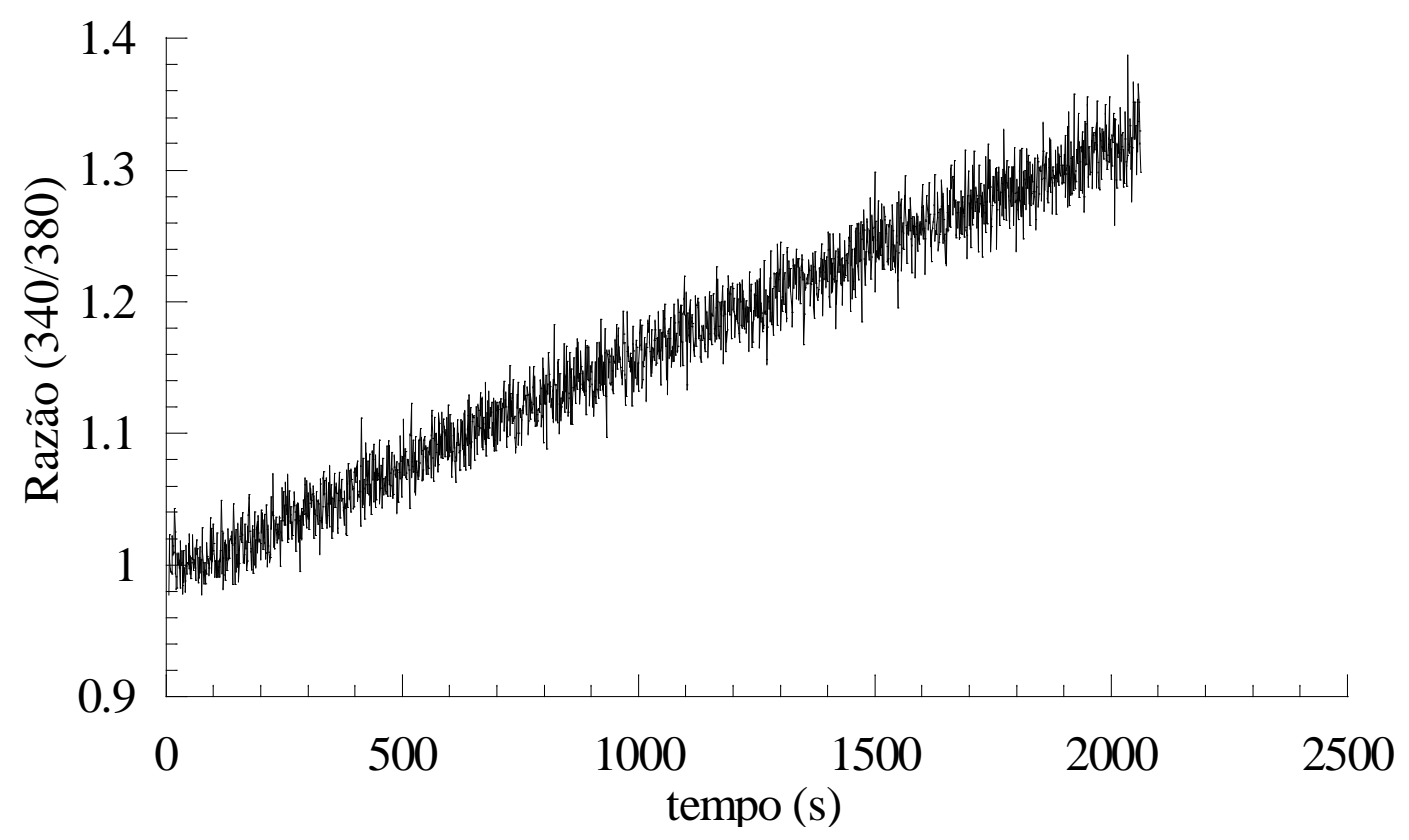

Figura 11: Gráfico representativo do aumento de cálcio citosólico promovido pela incubação de células secretoras da glândula de veneno de Bothrops jararaca com propranolol $\left(10^{-4} \mathrm{M}, 30\right.$ minutos, $\left.n=3\right)$. 


\subsection{PKA participa da regulacão de canais de cálcio no estado basal das células}

A estímulação do adrenoceptor $\beta$ com isoprenalina promove aumento de AMPc em células secretoras quiescentes (YAMANOUYE et al., 2000) e este pode levar à ativação de PKA, que pode desencadear um aumento de cálcio citosólico (BRUCE et al., 2002; DOLGACHEVA et al., 2003). Para determinar se o aumento de cálcio citosólico desencadeado pela estimulação do adrenoceptor $\beta$ seria devido a ativação de PKA, foi utilizado um inibidor de PKA (PKI, $\left.10^{-6} \mathrm{M}\right)$. Os resultados mostraram que PKI, por si só, é capaz de promover um aumento de cálcio citosólico em células em meio nominalmente sem cálcio e em meio com 2,5 mM de cálcio ( $n=4$, Figura 12a e 12b, respectivamente). 
a

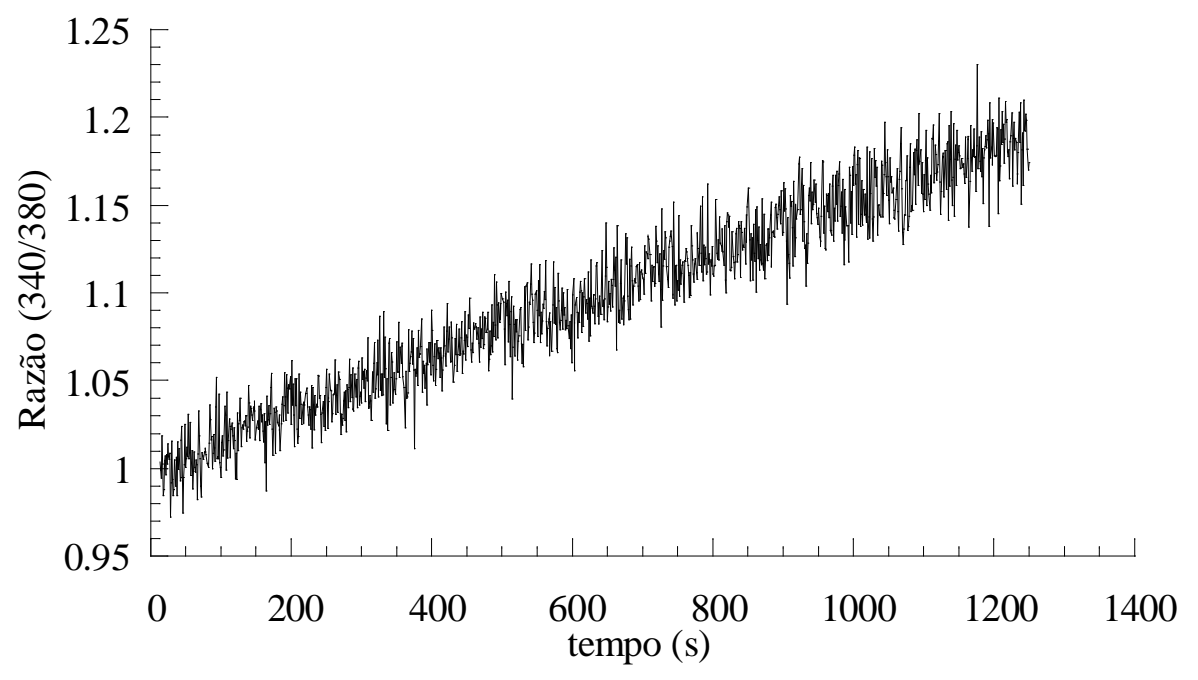

b

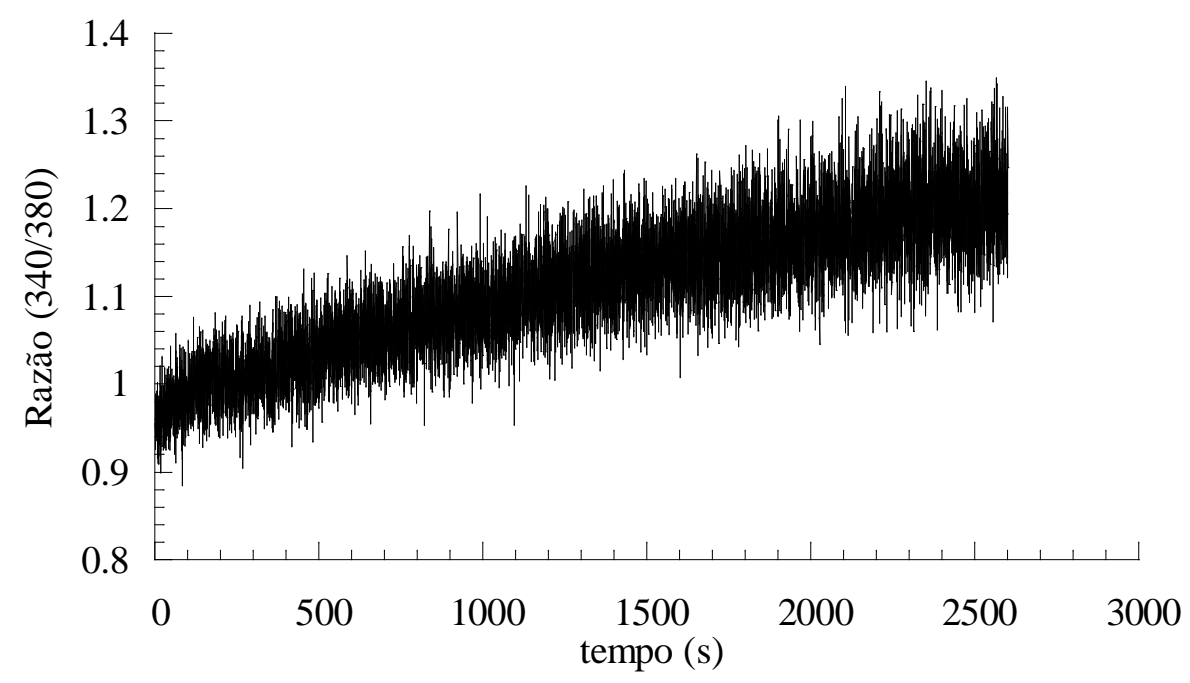

Figura 12: Gráficos representativos do aumento de cálcio citosólico promovido pela incubação de células secretoras quiescentes da glândula de veneno de Bothrops jararaca com PKI (10-6 M, 30 minutos). a: células em solução Krebes-Hepes com $2,5 \mathrm{mM}$ de cálcio $(n=4)$. b: células em solução Krebs-Hepes nominalmente sem cálcio $(n=4)$. 


\subsection{O adrenoceptor $\beta$ desencadeia o ciclo de producão de veneno}

A inervação noradrenérgica é importante para o ciclo de produção de veneno em serpentes Bothrops jararaca, uma vez que o tratamento de animais com reserpina, droga que depleta os estoques de noradrenalina, inibe o ciclo de produção e secreção de veneno (YAMANOUYE et al., 1997). No entanto, se o tratamento com reserpina é acompanhado por um tratamento crônico (11 dias) com isoprenalina, reverte-se parcialmente o bloqueio promovido por reserpina, ocorrendo a expansão de cisternas do retículo endoplasmático e, conseqüentemente, a restauração da produção de veneno (YAMANOUYE et al., 1997). No entanto, foi demonstrado neste trabalho, através dos dados de fluorimetria, e em trabalho anterior do laboratório (YAMANOUYE et al., 2000) que o adrenoceptor $\beta$ sofre dessensibilização após sua estimulação. Assim, tornou-se interessante verificar se apenas uma dose de agonista poderia ser suficiente para o desencadeamento do ciclo de produção de veneno.

Os resultados obtidos demonstraram que as glândulas de veneno de animais que sofreram extração de veneno (ativação do ciclo de produção de veneno) e tratados com reserpina por 15 dias, não produzem nem secretam veneno, uma vez que as cisternas do retículo endoplasmático estão estreitas e paralelas e o complexo de Golgi está quiescente, indicativo da ausência de síntese e secreção de veneno, respectivamente (figura 13a). Já nos animais tratados com reserpina por 15 dias e com uma única dose de isoprenalina após a extração de veneno, verificamos que nas células secretoras da glândula de veneno, as cisternas do retículo endoplasmático estão expandidas e complexo de Golgi ativo, ou seja, tanto a produção quanto a 
secreção de veneno são restauradas (figura 13b). Assim, uma única estimulação do adrenoceptor $\beta$ é capaz de desencadear o ciclo de produção e secreção de veneno. 
a

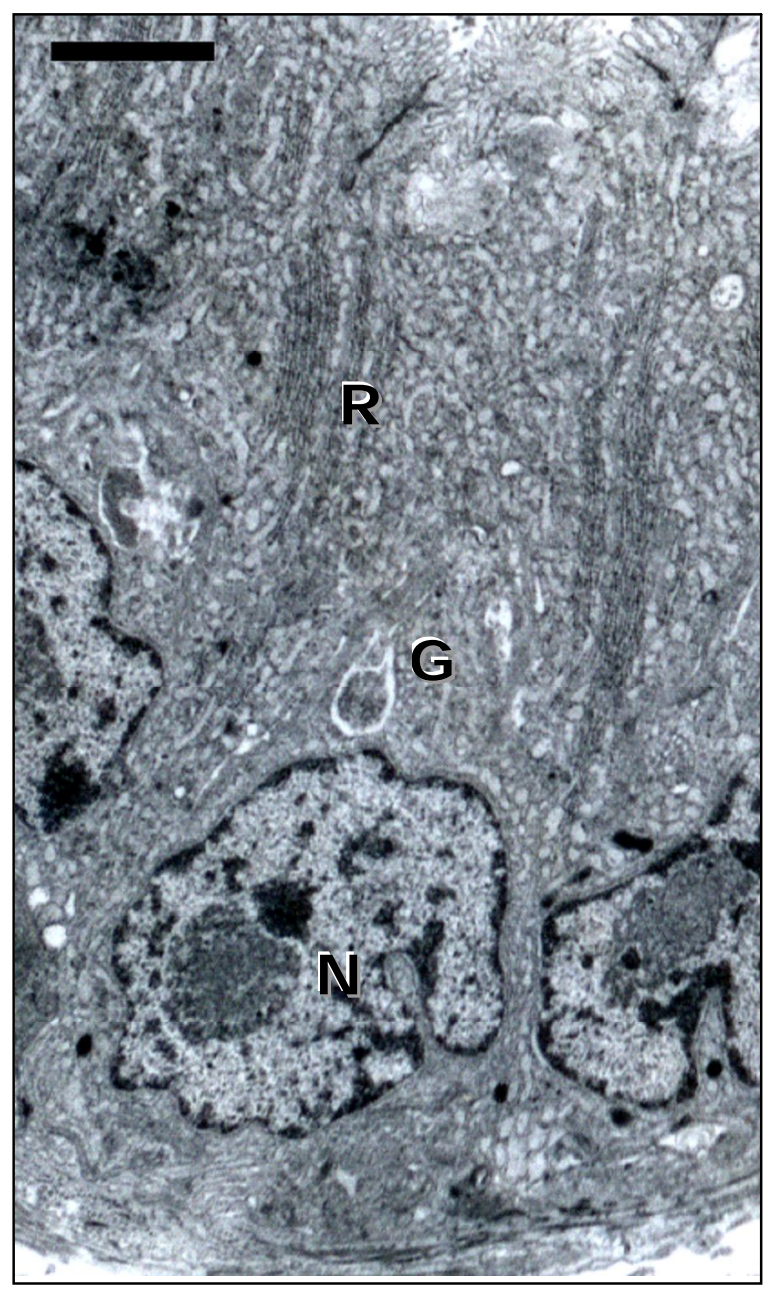

b

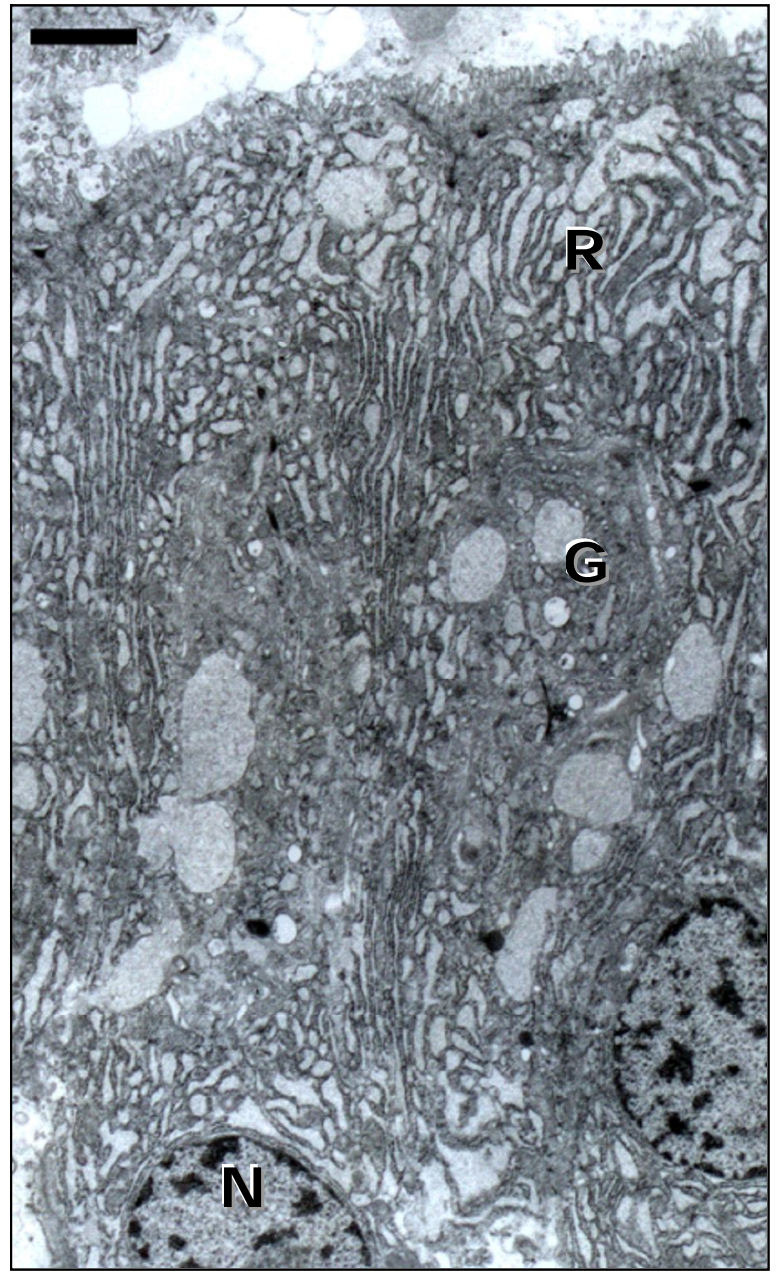

Figura 13: Efeito de uma única dose de isoprenalina (100 mg/kg, s.c.) sobre a produção e secreção de veneno em células secretoras da glândula de veneno da serpente Bothrops jararaca que sofreram extração de veneno e foram tratadas com reserpina durante o ciclo de produção de veneno. a: glândula de veneno obtida de serpentes tratadas com reserpina por 15 dias apresenta cisternas do retículo endoplasmático paralelas e Golgi inativo, indicando o bloqueio da produção e secreção de veneno. b: glândula de veneno de animais tratados com reserpina e isoprenalina ( 1 dose após extração de veneno) apresenta retículo com cisternas expandidas e vesículas no complexo de Golgi, indicando produção e secreção de veneno. $\mathrm{G}$, complexo de Golgi; $\mathrm{R}$, retículo endoplasmático granular; $\mathrm{N}$, núcleo. Barra $=2 \mu \mathrm{m}$. 


\section{DISCUSSÃO}

A inervação noradrenérgica presente em glândula de veneno da serpente Bothrops jararaca possui um papel relevante para o ciclo de produção de veneno e a estimulação de ambos os adrenoceptores $\alpha$ e $\beta$ está envolvida neste processo (YAMANOUYE et al., 1997).

O adrenoceptor $\beta$ da glândula de veneno de Bothrops jararaca possui características farmacológicas diferentes dos descritos em mamíferos, com baixa afinidade a ligantes $\beta_{1}, \beta_{2}$ e $\beta_{3}$ seletivos e está presente tanto em células quiescentes, como em células no pico máximo de ativação. A estimulação deste adrenoceptor promove aumento na concentração intracelular de AMPc somente em células secretoras quiescentes, sugerindo que em células secretoras ativadas esse receptor está dessensibilizado (YAMANOUYE et al., 2000).

Nesta dissertação, mostramos que o adrenoceptor $\beta$ está acoplado a diversas vias de sinalização. A estimulação do adrenoceptor $\beta$, além de ativar a adenilil ciclase (YAMANOUYE et al, 2000), é capaz de ativar canais de cálcio ativados por voltagem e por receptor e mobilizar cálcio de estoques sensíveis à tapsigargina, mas somente em células secretoras no estado quiescente. Além disso, o aumento da taxa de acidificação do meio extracelular causado por isoprenalina parece estar acoplado a outra via de sinalização, visto que esta resposta é semelhante em células secretoras quiescentes e ativadas por 4 dias. Mostramos também que a estimulação do adrenoceptor $\beta$ é essencial para desencadear o ciclo de produção de veneno.

A utilização de propranolol, bloqueador não seletivo de adrenoceptor $\beta$, confirmou a ação de isoprenalina em adrenoceptores $\beta$ em aumentar a taxa de 
acidificação do meio extracelular. No entanto, a participação de adrenoceptor $\beta$ no aumento da concentração citosólica de cálcio promovida por isoprenalina não pode ser verificada, pois propranolol por si só levou a um aumento crescente de cálcio citosólico tanto em células em meio com cálcio, como em meio nominalmente sem cálcio. Esse efeito pode ser explicado pelo fato do propranolol ter características anfifílicas e modificar as propriedades físico-químicas das membranas, modulando a síntese de lipídios e a sinalização intracelular de cálcio, independentemente da ativação de receptores (BOBEZSKO et al., 2002). Atuando em membranas, propranolol pode ativar a síntese de fosfatidiletanol e ácido fosfatídico mediada por fosfolipase D (CHAl et al., 2001; BOBEZSKO et al., 2002) e também inibir PKC (SOZZANI et al., 1992; WANDERLEY et al., 2000). Apesar disso, podemos creditar o efeito de isoprenalina em aumentar a concentração citosólica de cálcio à estimulação dos adrenoceptores $\beta$, visto que foi comprovada a ação de isoprenalina nesse receptor em células secretoras da glândula de veneno da serpente Bothrops jararaca, promovendo aumento de AMPc (YAMANOUYE et al, 2000) e da taxa de acidificação extracelular.

O aumento da concentração de cálcio citosólico foi bem maior em células secretoras quiescente do que em células ativadas por 4 dias. Esse resultado corrobora com o dados obtidos por Yamanouye et al (2000), onde isoprenalina foi capaz de aumentar a concentração de AMPc somente em células secretoras quiescentes, sugerindo que o adrenoceptor $\beta$ da glândula de veneno sofre dessensibilização logo após sua estimulação.

Entretanto, isoprenalina foi capaz de aumentar a taxa de acidificação do meio extracelular tanto em células quiescentes com em células ativadas por 4 dias. Esse 
dado aparentemente contrapõe-se à dessensibilização do adrenoceptor $\beta$ após sua estimulação. Uma hipótese para o aumento semelhante na taxa de acidificação do meio extracelular nas células secretoras, nos dois estágios, seria a de que, nas células ativadas por 4 dias, isoprenalina poderia estar levando a um pequeno aumento de AMPc não detectável pelos ensaios utilizados (YAMANOUYE et al., 2000) e que esta pequena quantidade de $\mathrm{AMPc}$, juntamente com $\mathrm{o}$ pequeno aumento de cálcio citosólico, seria capaz de promover o aumento na taxa de acidificação do meio extracelular, uma vez que este é um efeito final da estimulação do receptor. Outra hipótese para a acidificação do meio extracelular em células secretoras ativadas por 4 dias, seria a ativação do fator regulador de troca $\mathrm{NA}^{+} / \mathrm{H}^{+}(\mathrm{NHERF})$ independentemente da ativação da proteína G. De acordo com Hall et al. (1998), agonistas podem promover a associação do domínio citoplasmático da região C-terminal do adrenoceptor $\beta_{2}$ com o domínio PDZ de NHERF, sendo que este último regula a atividade do trocador $\mathrm{Na}^{+} / \mathrm{H}^{+}$do tipo 3 (NHE3), que modula o $\mathrm{pH}$ extracelular.

O cálcio é um íon extremamente importante para a sinalização celular e participa de diferentes processos, de sinalizações locais a sinalizações extremamente amplas e complexas, podendo chegar, quando em níveis muito altos, à apoptose (BERRIDGE et al., 1999). Por isso, os organismos desenvolveram um controle muito rígido deste íon. O equilíbrio é encontrado através do balanço entre a entrada de cálcio no citosol e a sua retirada para o meio extracelular ou para estoques intracelulares através de bombas cálcio-ATPase da membrana plasmática e do retículo endoplasmático (BERRIDGE et al., 1997), respectivamente. 
Nas células secretoras quiescentes da glândula de veneno, o cálcio parece exercer um papel importante na produção de veneno, pois tanto a estimulação do adrenoceptor $\alpha$ (KERCHOVE, 2005) quanto do adrenoceptor $\beta$ levam a um aumento da concentração citosólica de cálcio. A estimulação do adrenoceptor $\alpha$ ativa a via da hidrólise do bifosfato de fosfatidilinositol, levando à produção de $\mathrm{IP}_{3}$ e $\mathrm{DAG}$, à liberação de cálcio de estoques sensíveis a tapsgargina e à ativação de PKC, respectivamente (KERCHOVE, 2005). Por sua vez, a estimulação do adrenoceptor $\beta$ aumenta a concentração citosólica de cálcio ativando canais de cálcio operados por voltagem do tipo L e canais operados por receptor, visto que diltiazem e SKF 96365, respectivamente, bloquearam esta resposta. Porém, enquanto a inibição do aumento de cálcio citosólico produzido por diltiazem foi parcial, SKF 96365 inibiu quase que totalmente essa resposta. Isso pode ser explicado pelo fato de SKF 96365 também agir, em alguns tipos celulares, em canais operados por voltagem (SCHWARTZ et al., 1994) ou também canais operados por estoques (DENYS et al., 2004). Vale a pena ressaltar que em glândula de veneno os canais operados por estoques também estão presentes e são ativados quando o estoque intracelular de cálcio é reduzido (KERCHOVE, 2005). Além disso, a estimulação dos adrenoceptores $\beta$ mobiliza cálcio de estoques intracelulares sensíveis a tapsigargina.

É interessante notar que embora a estimulação de ambos adrenoceptores $\alpha$ e $\beta$ desencadeiem um aumento da concentração de cálcio citosólico, a cinética da resposta é diferente. Fenilefrina promove um aumento rápido na concentração de cálcio citosólico (KERCHOVE, 2005), enquanto que isoprenalina promove um aumento lento. Em outros tecidos como em adipócitos brancos diferenciados de humanos (SEYDOUX 
et al., 1996) e em pré-adipócitos marrons de camundongos (DOLGACHEVA et al., 2003), a ativação de adrenoceptores $\beta$ também promove aumento lento na concentração de cálcio citosólico. Entretanto, os mecanismos que promovem este aumento ainda não foram elucidados.

Em células secretoras da glândula de veneno de Bothrops jararaca, a estimulação do adrenoceptor $\beta$ promove a ativação da adenilil ciclase e, consequentemente, aumento na concentração de AMPc (YAMANOUYE et al., 2000). O AMPc, por sua vez, promove a ativação de PKA, que pode fosforilar vários substratos e, com isso, promover diversas respostas como a abertura de canais de cálcio. Entretanto, verificamos que em células secretoras, o aumento de cálcio verificado após a estimulação dos adrenoceptores $\beta$ não é via PKA, diferente do que ocorre em ducto de glândula submandibular de ratos, onde PKA promove fosforilação dos receptores de $\mathrm{IP}_{3}$ e, com isso, leva a um aumento da concentração de cálcio citosólico promovido por isoprenalina (NEZU et al., 2000; BRUCE et al., 2002). O inibidor de PKA utilizado, PKI, promoveu por si só um aumento na concentração citosólica de cálcio, sugerindo que PKA tem um papel importante na regulação de canais de cálcio nas células secretoras no estado quiescente. Estes dados sugerem que os mecanismos pelos quais isoprenalina promove um aumento de cálcio citosólico são dependentes do tipo celular. Corroborando com essa hipótese, foi mostrado que em miócitos da veia portal de coelhos, a estimulação do adrenoceptor $\beta$ promove influxo de cálcio mediado pela subunidade $G \beta \gamma$ da proteína $G_{s}$, através de PKC (ZHONG et al., 2001). Além disso, a fosforilação do adrenoceptor $\beta$ pode também promover a acoplamento à proteína $\mathrm{G}_{\mathrm{i}, \text {, }}$ sendo que a subunidade G $\beta \gamma$ desta proteína pode ativar PLC e, com isso, promover um 
aumento de $\mathrm{IP}_{3}$, levando a mobilização de cálcio de estoques intracelulares (LUO et al., 1999; MARTIN et al., 2004; UEZONO et al., 2004).

As proteínas ligadoras de cálcio (CaBPs) estão envolvidas na regulação de muitas atividades celulares, como a regulação de atividades enzimáticas, translocação e tamponamentos de cálcio. As CaBPs estão presentes não apenas na glândula de veneno, como também no veneno da serpente Bothrops jararaca. Parvalbumina e calbindina estão presentes nas células secretoras, enquanto que a CaBP semelhante a calmodulina está presente tanto nas células secretoras como também no veneno (GONÇALVES et al., 1997). Na glândula de veneno da serpente Bothrops insularis foi encontrada a proteína calglandulina, um novo membro da família das CaBPs, que está presente também em glândulas de veneno de outros membros da família Viperidae, como Bothrops jararaca e Crotalus durissus terrificus (JUNQUEIRA DE AZEVEDO et al., 2003). As CaBPs tem um papel fundamental em controlar a concentração citosólica de cálcio em glândulas salivares e calmodulina parece estar envolvida nos processos de exocitose através da regulação do citoesqueleto (TOJYO et al., 1987; 1989). Portanto, a presença de CaBPs na glândula de veneno corroboram com a hipótese de que o cálcio tem um papel relevante na dinâmica da glândula de veneno de serpentes da família Viperidae.

Após a estimulação dos adrenoceptores ocorre o processo de dessensibilização, que é um mecanismo que previne uma superestimulação dos receptores face a uma exposição excessiva a agonistas. Este processo pode durar de segundos a horas, dependendo do tecido e do grau de exposição ao agonista e é composto por 3 mecanismos principais: desacoplamento do receptor da proteína $G$, internalização do receptor e degradação ou reciclagem do receptor. O mecanismo mais rápido de 
dessensibilização ocorre pela ação de proteínas quinases (PKA e GRK, por exemplo), que fosforilam os resíduos serina e treonina das alças intracelulares e da região Cterminal do receptor, e pela ação de arrestinas, que se acoplam ao receptor fosforilado e promovem o desacoplamento do receptor da subunidade $\mathrm{G} \alpha$ da proteína $\mathrm{G}$. A internalização do receptor é um processo um pouco mais longo de dessensibilização e é mediado por $\beta$-arrestinas que, junto com outras proteínas, promovem o seqüestro do receptor da superfície celular e o seu transporte para o citoplasma. Uma vez no citoplasma, o receptor pode ter 2 destinos: a reciclagem, que consiste na desfosforilação do receptor e seu retorno à membrana, ou então a degradação deste receptor. Neste último caso, somente após a produção de novos receptores é que ocorre o retorno destes à membrana plasmática (para revisão ver FERGUSON, 2001; JOHNSON, 1998; 2006). Portanto, a dessensibilização do adrenoceptor $\beta$ após sua estimulação é um processo auto-regulatório comum, que está relacionado com a exposição ao agonista e que visa prevenir o colapso da célula pelo excesso de estimulação.

Neste trabalho, demonstramos que o adrenoceptor $\beta$ células secretoras da glândula de veneno de Bothrops jararaca sofre longa dessensibilização após sua estimulação, uma vez que dura no mínimo 4 dias. $O$ adrenoceptor $\alpha$ de células secretoras também sofre dessensibilização após sua estimulação, sendo que esta dessensibilização dura aproximadamente 30 dias, justamente o período de duração do ciclo de produção de veneno (KERCHOVE, 2005). Esses dados reforçam a hipótese de que esses receptores possuem características diferentes dos adrenoceptores descritos 
em literatura e mostram sua importância no desencadeamento do ciclo de produção de veneno.

É interessante notar que apenas uma administração de isoprenalina restaurou o processo de síntese e secreção de veneno em serpentes reserpinizadas. A exposição prolongada ao agonista isoprenalina em células secretoras da glândula de veneno de Bothrops jararaca, através de um tratamento crônico, parece promover uma dessensibilização cruzada com outros receptores que devem participar do processo de secreção de veneno, visto que apenas o processo de produção de veneno foi restaurada e não o da secreção (YAMANOUYE et al., 1997).

Apesar do adrenoceptor $\beta$ possuir um papel importante na secreção de proteínas salivares em glândulas salivares (WATSON et al., 1984; LI et al, 2006; QUISSELL et al., 1993; QUISSELL \& BARZEN, 1980; YAMADA et al., 2006), parece que o adrenoceptor $\beta$ da glândula de veneno não está envolvido na secreção de toxinas, visto que a produção de toxinas começa ao redor do quarto dia após a extração de veneno, período em que este receptor encontra-se dessensibilizado. A hipótese mais provável é que a estimulação do adrenoceptor $\beta$ leve a produção de proteínas da glândula de veneno, levando à sua ativação. Corroborando com essa hipótese, Nuñes-Burgos, et al. (1993) mostraram que o tratamento crônico com isoprenalina em serpentes Bothrops jararaca promove mudanças no perfil protéico da glândula de veneno. Além disso, em glândulas parótidas de camundongos, a estimulação do adrenoceptor $\beta$ promove mudanças nos padrões de expressão gênica desta glândula (TEN HAGEN et al., 2002). Dados recentes do laboratório também mostraram que a estimulação do adrenoceptor $\beta$ promove a ativação de fatores de transcrição em células secretoras da 
glândula de veneno no estado quiescente, regulando a síntese de proteínas da glândula de veneno e levando à sua ativação (dados não publicados).

Os dados obtidos neste trabalho somam aos já obtidos no laboratório (YAMANOUYE et al., 2000) mostrando que o adrenoceptor $\beta$ possui características farmacológicas diferentes dos descritos para mamíferos e que a estimulação desse receptor desencadeia uma sinalização intracelular complexa nas células secretoras da glândula de veneno da serpente Bothrops jararaca. Além disso, esse receptor é fundamental para o desencadeamento do ciclo de produção de veneno.

Este estudo é de fundamental importância para o entendimento da dinâmica da glândula de veneno, onde a compreensão dos mecanismos envolvidos na produção e secreção de veneno será de grande valia para o estabelecimento de uma linhagem de células secretoras funcionais que produza veneno in vitro, com atividade biológica semelhante ao veneno obtido da serpente. 


\section{CONCLUSÕES}

- O adrenoceptor $\beta$ de células secretoras da glândula de veneno de Bothrops jararaca é importante para desencadear o ciclo de produção e secreção de veneno, visto que sofre dessensibilização logo após sua estimulação;

- A estimulação do adrenoceptor $\beta$ leva à ativação de diferentes vias de sinalização tais como ativação de adenilil ciclase, canais de cálcio operado por voltagem e por receptor e mobilização de cálcio de estoques intracelulares;

- PKA possui um papel importante na regulação de canais de cálcio de células no estado basal. 


\section{REFERÊNCIAS BIBLIOGRÁFICAS}

AMSTERDAM, A.; OHAD, I.; SCHRAMM, M. Dynamic changes in the ultrastructure of acinar cell of the rat parotid gland during the secretory cycle. J Cell Biol, v.41, n.3, Jun, p. 753-773, 1969.

ANN, D. K.; LIN, H. Transcriptional regulation of salivary proline-rich protein gene expression. Ann. N.Y. Acad. Sci. 842, 108-114, 1998.

BDOLAH, A. The venom glands of snakes and venom secretion. In: Snake Venom, Ed. C.Y. Lee, Berlin, Springer Verlag,. p. 41-57. (Handb. Exp. Pharmacol., 52), 1979.

BELLUOMINI, H.E. Extraction and quantities of venom obtained from some Brazilian snakes. In: Venomous Animals and Their Venoms Eds. W. Bucherl, V. Buckley, V. Deulofeu. New York, Academic Press,V. I, p. 97-117, 1968.

BEN-SHAUL, Y.; LIFSHITZ, S.H.; KOCHVA, E. Ultrastructural aspects of secretion in the venom glands of Vipera palaestinae. In: Toxins of Animal and Plants Origin, Eds. A. De Vries, E. Kochva, London, Gordon and Breach. p. 87-105, 1971.

BERRIDGE, M.J. Elementary and global aspects of calcium signalling. J. Exp. Biol., 200, p. 315-319, 1997.

BERRIDGE, M.J.; LIPP, P.; BOOTMAN, M. Calcium signalling, Curr. Biology, v9, n5, p. R157-158, 1999

BOBESZKO, M.; CZAJKOWSKI, R.; WOJCIK, M.; SABALA, P.; NAPELA, I.; BARANSKA, J. Modulation by cationic amphiphilic drugs of serine base-exchange, phospholipase D and intracellular calcium homeostasis in glioma C6 cells. Pol. J. Pharmacol., 54, p. 483-93, 2002.

BRENO, M.C.; YAMANOUYE, N.; PREZOTO, B.C.; LAZARI, M.F.M.; TOFFOLETTO, O.; PICARELLI, Z.P. Maintenance of the snake Bothrops jararaca (Wied, 1824) in captivity. The Snake, v.22, n. 2, Dec, p. 126-130, 1990.

BRUCE, J.I.E.; SHUTTLEWORTH, T.J.; GIOVANNUCCI, D.R.; YULE, D.I. Phosphorylation of inositol 1,4,5-triphosphate receptors in parotid acinar cells. J. Biol. Chem., 277, p. 1340-1348, 2002.

CARDOSO, J.L.C.; FRANÇA, F.O.S.; WEN, F.H.; MÁLAQUE, C.M.S.; HADDAD Jr, V. Animais peçonhentos no Brasil. São Paulo: Sarvier, 2003, 468 p.

CARNEIRO, S.M.; PINTO, V.R.; JARED, C.; LULA, L.A.B.M.; FARIA, F.P.; SESSO, A. Morphometric studies on venom secretory cells from Bothrops jararacussu (jararacuçu) before and after venom extraction. Toxicon, v.29, n.6, Oct, p. 569-580, 1991. 
CATTERALL, W.A., REYES, E.P.; SNUTCH, T.P.; STRIESSING, J. International Union of Pharmacology XLVIII. Nomenclature and Structure-Function relationships of voltage gated calcium channels. Pharmacol Rev, 57, p. 411-425, 2005.

CHAI, M.Q.; CHEN, J.S.; ZHAO, S.; SONG, J.G. Propranolol increases phosphatidic acid level via activation of phospholipase D. Acta Pharmacol. Sin. 22, p. 777-784, 2001.

CLAPHAM, D.E.; RUNNELS, L.W.; STRUBING, C. The TRP ion channel family. Nat Rev Neurosci, 2, p. 387-396, 2001.

CLAPHAM, D.E.; JULIUS, D.; MONTELL, C.; SCHULTZ, G. International Union of Pharmacology XLIX. Nomenclature and Structure-Function relationships of transient receptor potential channels. Pharmacol Rev, 57, p. 427-450, 2005.

DE LUCCA, F.L.; HADDAD, A.; KOCHVA, E.; ROTHSCHILD, A.M.; VALERI, V. Protein synthesis and morphological changes in the secretory epithelium of the venom gland of Crotalus durissus terrificus at different times after manual extraction of venom. Toxicon, v.12, n.4, Aug, p. 361-368, 1974.

DENYS, A.; AIRES, V.; HICHAMI, A., KHAN, N.A. Thapsigargin-stimulated MAP kinase phosphorylation via CRAC channels and PLD activation: inhibitory action of docosahexaenoic acid. FEBS Letters, 564, p. 177-182, 2004.

DOLGACHEVA, L.P.; ABZHALELOV, B.B.; ZHANG, S.J.; ZINCHENKO, V.P.; BRONNIKOV, G.E. Norepinephrine induces slow calcium signaling in murine brown preadipocytes through the $\beta$ adrenoceptor/cAMP/protein kinase A pathway. Cell. Signal. 15, p. 209-216, 2003.

DOLMAN, N.J.; TEPIKIN, A.V. Calcium gardients and the Golgi. Cell Calcium, 40, p. 505-512, 2006.

ENDOH, M. Signal transduction and calcium signaling in intact myocardium. J Pharmacol Sci,100, p. 525-537, 2006.

FERGUSON, S.S.G. Evolving concepts in G-protein- coupled receptors endocytosis: the role in receptor desensitization and signaling. Pharmacol Rev, 53, p. 1-24, 2001.

FREDRIKSSON, R.; LARGESTROM, M.C.; LUNDIN, L.G.; SCHIOTH, H.B. The Gprotein- coupled receptors in the human genome form five main families. Philogenetic analysis, paralogon groups and fingerprints. Mol Pharmacol, 63, p. 1256-1272, 2003. 
FUNDAÇÃO NACIONAL DE SAÚDE (FUNASA, Brasília, DF). Manual de diagnóstico e tratamento de acidentes por animais peçonhentos, $2^{\circ}$ edição, Brasília, FUNASA MS, 2001, $112 \mathrm{p}$.

GANITKEVICH, V.Y. The role of mitochondria in cytoplasmic calcium signaling. Exp Phisiol, 88, p. 91-97, 2003.

GETHER, U. Uncovering molecular mechanisms involved in activation of G-proteincoupled receptors. Endocrin Rev, 21, p. 90-113, 2000.

GOMES, N.; PUORTO, G. Atlas anatômico de Bothrops jararaca, Wied, 1824 (Serpentes: Viperidae). Mem Inst Butantan, v.55, n.1, p. 69-100, 1993.

GONÇALVES, L.R.C; YAMANOUYE, N.; NUNEZ-BURGOS, G.B.; FURTADO, M.F.; BRITTO, L.R.G; NICOLAU, J. Detection of calcium -binding proteins in venom and duvernoy's glands of south American snakes and their secretions. Comp Biochem Physiol C, v.118, n. 2, p. 207-211, 1997.

GOPALAKRISHNAKONE, P.; KOCHVA, E. Unusual aspects of the venom apparatus of the blue coral snake, Maticora bivirgata. Arch Histol Cytol, v.53, n.2, May, p. 199-210, 1990.

GOPALAKRISHNAKONE, P.; KOCHVA, E. Histological features of the venom apparatus of sea snake Lapemis curtus. Snake v.25, p. 27-37, 1993.

HALL, R.A.; PREMOSNT, R.T.; CHOW, C.W.; BLITZER, J.T.; PITCHER, J.A.; CLAING, A.; STOFFEL, R.H.; BARAK, L.S.; SHENOLIKAR, S.; WEINMAN, E.J.; GRINSTEIN, S.; LEFKOWITZ, R.J. The $\beta 2$-adrenergic receptor interacts with the $\mathrm{Na}+/ \mathrm{H}+$-exchanber regulatory factor to control $\mathrm{Na}+/ \mathrm{H}+$ exchange. Nature 392 (6676), p. 626-630, 1998.

HEPLER, J.R. Emerging roles for RGS proteins in cell signalling. Trends Pharmacol Sci, 20, p. 376-382, 1999.

HOFMANN, F.; BIEL, M.; KAUPP, B. International Union of Pharmacology. LI. Nomenclature and Structure-Function relationships of cyclic nucleotide channels. Pharmacol Rev, 57, p. 455-462, 2005.

JAMIESON, J.D.; PALADE, G.E. Intracellular transport of secretory proteins in the pancreatic exocrine cell. I Role of the peripheral elements of the Golgi complex. J Cell Biol, v.34, n.2, Aug, p. 577-596, 1967a.

JAMIESON, J.D.; PALADE, G.E. Intracellular transport of secretory proteins in the pancreatic exocrine cell. II Transport to condensing vacuoles and zymogen granules. $\mathbf{J}$ Cell Biol, v.34, n.2, Aug, p.597-615, 1967b. 
JOHNSON, M. The $\beta$-Adrenoceptor. Am J Respir Crit Care Med, 158, p. S146-S153, 1998.

JOHNSON, M. Molecular mechanisms of beta(2)-adrenergic receptor function, response and regulation. J Allergy Clin Immunol, 117, p. 18-24, 2006.

JUNQUEIRA-DE-AZEVEDO I. de L.; PERTINHEZ, T.; SPISNI, A.; CARRENO, F.R.; FARAH, C.S.; HO, P.L. Cloning and expression of calglandulin, a new EF-hand protein from the venom glands of Bothrops insularis snake in E. coli. Biochim Biophys Acta, v. 1648, n.1-2, May 30, p. 90-8, 2003.

KARDONG, K.V. The evolution of snakes apparatus in snakes from colubrids to viperids \& elapids. Mem Inst Butantan, v.46, p. 105-118, 1982.

KAUPP, U.B.; SEIFERT, R. Cyclic nucleotide-gated ion channels. Physiol Rev, 82, p. 769-824, 2002.

KAZNACHEYEVA, E.; GLUSHANKOVA, L.; BUGAJ, V.; ZIMINA, O., SKOPIN, A., ALEXEENKO, V.; TSIOKAS, L.; BEZPROZVANNY, I.; MOZHAYEVA, G.N. Supression of TRPC3 leads to disappearance of stored-operated channels and formation of a new type of store-independent channels in A431 cells. J Biol Chem, p. 1-18, 2007.

KERCHOVE, C.M. Adrenoceptor alfa da glândula de veneno de Bothrops jararaca: aspectos funcionais e moleculares. $115 \mathrm{f}$. Tese (Doutorado em Ciências) - Instituto de Ciências Biomédicas, Universidade de São Paulo, São Paulo, 2005.

KERCHOVE, C.M.; CARNEIRO, S.M.; MARKUS, R.P.; YAMANOUYE, N. Stimulation of the alfa adrenoceptor triggers the venom production cycle in the venom gland of Bothrops jararaca. J. Exp. Biol. 207, p. 411-416, 2004.

KOCHVA, E. Oral glands of the Reptilia. In: Biology of the Reptilia, Ed. C. Gans, London, Academic Press. p. 43-161. vol. 8B, 1978.

KOCHVA, E. The origin of snakes and evolution of the venom apparatus. Toxicon, v.25, n.1, p. 65-106, 1987.

KOCHVA, E.; GANS, C. The structure of the venom gland and secretion of venom in viperid snakes. In: Animal Toxins, Eds. F.E. Russell, P.R. Saunders. Oxford, Pergamon press, p. 195-203, 1967.

KOCHVA, E.; GANS, C. Salivary glands of snakes.Clin Toxicol, 3, 363-387, 1970.

KOCHVA, E.; ORON, U.; OVADIA, M.; SIMON, T.; BDOLAH, A. Venom glands, venom synthesis, venom secretion and evolution. In: Natural Toxins, Eds. D. Eaker, T Wadströn, Oxford, Pergamon Press, p. 3-12, 1980. 
LI, Y.M.; ZHANG, Y.; XIANG, B.; ZHANG, Y.Y.; WU, L.L.; YU, G.Y. Expression and functional analysis of beta-adrenoceptor subtypes in rabbit submandibular gland. Life Sci, 26, p. 2091-2098, 2006.

LUO, X.; ZENG, W.; XU, X.; POPOV, S.; DAVIGNON, I.; WILKIE, T.M.; MUMBY, S.M.; MUALLEM, S. Alternate coupling of receptors to $G$ s and $G i$ in pacreatic and submandibular gland cells. J. Biol. Chem. 274, p. 17684-17690, 1999.

MACKESSY, S.P. Morphology and ultrastruture of the venom gland of the northen pacific rattlesnake Crotalus viridis oreganus. J Morphol, v.208, p. 109-128, 1991.

MALBON, C.C. G proteins in development. Nature Reviews, v6, p. 689-701, 2005.

MARTIN, N.P.; WHALEN, E.J.; ZAMAH, M.A.; PIERCE, K.L.; LEFKOWITZ, R.J. PKA mediated phosphorilation of the $\beta 1$ adrenergic receptor promotes $\mathrm{Gs} / \mathrm{Gi}$ switching. Cell. Signal., 16, p. 1397-1403, 2004.

MARTINEZ, J.R. Developmental aspects of fluid electrolyte secretion in salivary glands. Crit. Rev. Oral Biol. Med. 5, p. 281-290, 1994.

MELDOLESI, J. Regulation of pancreatic exocrine secretion. Pharmacol Res Commun, 8, p. 1-24, 1976.

NEZU, A.; TANIMURA, A.; TOJYO, Y. Characterization of the $\mathrm{Ca}^{2+}$ response mediated by activation of $\beta$-Adrenoceptors in rat submandibular ducts. Jpn $\mathbf{J}$ Pharmacol 84, p. 25-31, 2000.

NEZU, A.; MORITA, T.; TANIMURA, A.; TOJYO, Y. Comparison of agonist-induced calcium responses in rat submandibular acini and ducts. Archives of Oral Biology, 50, p. 585-592, 2005.

NOWYCKY, M.C.; THOMAS, A.P.; Intracellular calcium signaling. J Cell Sci, 115, p. 3715-3716, 2002.

NUÑES-BURGOS, G.B.; GONÇALVES, L.R.C.; FURTADO, M.F.D.; FERNANDES, W.; NICOLAU, J. Alteration of the protein composition of bothrops jararaca venom and venom gland by isoproterenol treatment. Int. J. Biochem. 25, p. 1491-1496, 1993.

ORON, U.; BDOLAH, A. Regulation of protein synthesis in venom gland of viperid snakes. J Cell Biol. 56, n.1, p. 177-90, 1973.

PEREZ, D.M.; KARNIK, S.S. Multiple signaling states of G-protein-coupled receptors. Pharmacol Rev, 57, p. 147-161, 2005. 
POLO-PARADA, L.; CHAN, S.A.; SMITH, C. An activity-dependent increased role for Itype calcium channels in exocytosis is regulated by adrenergic signaling in chromaffin cells. Neuroscience, 143, p. 445-459, 2006.

QUISSELL, D.O.; BARZEN, K.A. Secretory response of disoersed rat submandibular cells. II. Mucin secretion. Am J Physiol, 238 (3), p. C99-106, 1980.

QUISSELL, D.O.; BARZEN, K.A.; DEISHER, L.M. Rat submandibular and parotid protein phosphorilation and exocytosis: effect of site-selective cAMP analogs. Critical Reviews in Oral Biology and Medicine, 4 (3/4), p. 443-448, 1993.

ROTENBERG, D.; BAMBERGER, E.S.; KOCHVA, E. Studies on ribonucleic and synthesis in the venom glands of Vipera palaestinae (Ophidia, Reptilia). Biochem $\mathbf{J}$, v.121, n.4, Feb, p. 609-612, 1971.

SALOMÃO, M.G. Estrutura e secreção das glândulas de Duvernoy de Sibynomorphus mikani (Colubridae, Dipsadinae) e Philodryas olfersii (Colubridae, Xenodontinae), e das glândulas de veneno de Bothrops jararaca (Viperidae, Crotalinae) e Micrurus frontalis (Elapidae, Elapinae) e a influência dos estados de alimentação e jejum. 122 f. Tese (Doutorado em Zoolologia), Instituto de Biociências, Universidade de São Paulo, São Paulo, 1991.

SATO, M.; KAWATANI, M. Effects of noradrenaline on cytosolic concentrations of calcium in cultured corpus cavernosum smooth muscle cells of the rabbit. Neuroscience Letters, 324, p. 89-92, 2002.

SCHWARTZ, G.; DROOGMANS, G.; NILIUS, B. Multiple effects of SKF 96365 on ionic currents and intracellular calcium in human endothelial cells. Cell Calcium, 15, p. 45-54, 1994.

SECOR, S. M., NAGY, K. Bioenergetic correlates of foraging mode for the snakes Crotalus cerastes and Masticophis flagellum. Ecology 75, p. 1600-1614, 1994.

SEYDOUX, J.; MUZZIN, P.; MOINAT, M.; PRALONG, W.; GIRARDIER, L.; GIACOBINO, J.P. Adrenoceptor heterogeneity in human white adipocytes differentiated in culture as assessed by cytosolic free calcium measurements. Cell Signal., 8 (2), p. 117-122, 1996.

SOZZANI , S.; AGWU, D.E.; MCCALLI, C.E.; O'FLAHERTY, J.T.; SCHMIDTT, J.D.; KENT, J.D.; McPHAIL, L.C. Propranolol, a phosphatidate phosphohydrolase inhibitor, also inhibits protein kinase C. J. Biol. Chem. 267, p. 20481-88, 1992.

STROSBERG, A.D.; NAHMIAST, C. G-protein-coupled receptor signalling through protein networks. Biochemical Society Transactions, v.35, part 1, p. 23-27, 2007. 
TEN HAGEN, K. G.; BALYS, M. M.; TABAK, L. A.; MELVIN, J. E. Analysis of isoproterenol-induced changes in parotid gland gene expression. Physiol. Genomics, 8, p. 107-114. 2002.

TOJYO, Y.; UCHIDA, M.; MATSUMOTO, Y. Inhibitory effects of calmodulin antagonists on isoproterenol and dibutyryl cyclic AMP-stimulated amylase release from rat parotid acinar cells. Japan J Pharmacol., 45, p. 487-491, 1987.

TOJYO, Y.; MATSUMOTO, Y.; OKOMURA, K.; KANAZAWA, M. The role of calmodulin in rat parotid amylase secretion: effectes of calmodulin antagonists on secretion and acinas cell structure. Japan J Pharmacol, 50, p. 149-157,1989.

UEZONO, Y.; KAIBARA, M.; MURASAKI, O.; TANIYAMA, K. Involvement of G protein $\beta \gamma$-subunits in diverse signaling induced by Gi/o-coupled receptors: study using Xenopus oocyte expression system. Am J Physiol Cell Physiol, 287, May, p. C885-894, 2004.

WANDERLEY, M.I.; UDRISAR, D.P.; MARTINS, M.C.; ANTUNES-RODRIGUES, J. Propranolol stimulates histone phosphorylation by a putative PKC in partially purified homogenate of rat testicular insterticial possible mechanism for increased testosterone secretion by propranolol. Horm Metab Res, 32, p. 259-64, 2000.

WARSHAWSKY, H.; HADDAD, A.; GONÇALVES, R.P.; VALERI, V.; DE LUCCA, F.L. Fine structure of the venom gland epithelium of the south American rattlesnake and radioautographic studies of protein formation by secretory cells. Am J Anat, v.138, n.1, Sep, p. 79-119, 1973.

WATSON, E.; DOWD, F.; JACOBSON, K.; HORWITZ, H. Reserpinization: Effects on parotid gland function. J Dent Res. 63, p. 82-86, 1984.

YAMADA, K.; INOUE, H.; SATOSHI, K.; MASUSHIGE, S.; NISHIYAMA, T.; MISHIMA, K.; SAITO, I. Involvement of CAMP Response Element-Binding Protein Activation in Salivary Secretion. Pathobiology, 73, Mar, p. 1-7.

YAMANOUYE, N.; BRITTO, L.R.G.; CARNEIRO, S.M.; MARKUS, R.P. Control of venom production and secretion by sympathetic outflow in the snake Bothrops jararaca. J Exp Biol, v.200, n.19, Oct, p. 2547-2556, 1997.

YAMANOUYE, N.; CARNEIRO, S.M.; SCRIVANO, C.N.; MARKUS, R.P. Characterization of $\beta$-adrenoceptors, responsible for venom production, in the venom gland of the snake Bothrops jararaca. Life Sci, v.67, n.3, Jun 8, p. 217-226, 2000.

YAMANOUYE, N.; KERCHOVE, C.M.; MOURA-DA-SILVA, A.M.; CARNEIRO, S.M.; MARKUS, R.P. Long term primary culture of secretory cells of Bothrops jararaca venom gland for venom production in vitro. Nature Protocols V1, 6, 2763-2766, 2007. 
YANG, W.; XIA, S.H. Mechanisms of regulation and function of G-protein-coupled receptor kinases. World J Gastroenterol, 12, p. 7753-7757, 2006.

YOSHIE, S.; ISHIYAMA, M.; OGAWA, T. Fine structure of duvernoy's gland of the japanese colubrid snake, Rhabdophis tigrinus . Arch histol jap, 45, p. 375-384, 1982

ZAGO, D.A. Estudo morfológico e histoquímico de glândulas salivares relacionadas com a evolução da função venenosa nos ofídeos. 69f. (Tese de Doutorado em Histologia) Instituto de Ciências Biomédicas, Universidade de São Paulo, São Paulo, 1971.

ZHONG, J.; HUME, J. R.; KEEF, K.D. $\beta$-Adrenergic receptor stimulation of L-type $\mathrm{Ca}^{2+}$ channels in rabit portal vein myocytes involves both $\alpha$ s and $\beta \gamma \mathrm{G}$ protein subunits. Jounal of Physiology 531.1, p. 105-115, 2001. 